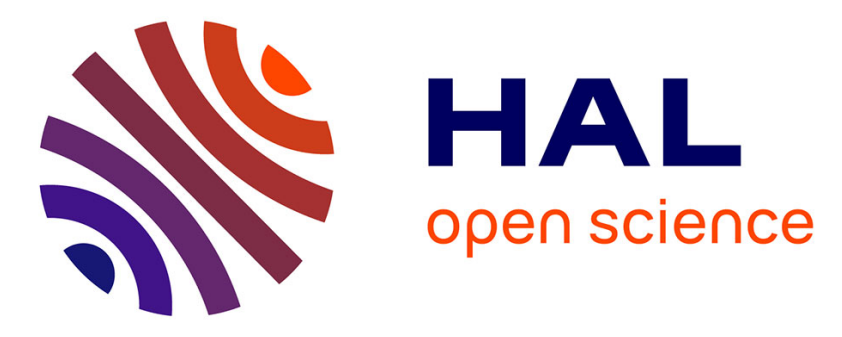

\title{
Effects of ocean acidification on trace element accumulation in the early-life stages of squid Loligo vulgaris
}

Thomas Lacoue-Labarthe, Elodie Reveillac, François Oberhänsli, Jean-Louis Teyssié, Ross Jeffree, Jean-Pierre Gattuso

\section{To cite this version:}

Thomas Lacoue-Labarthe, Elodie Reveillac, François Oberhänsli, Jean-Louis Teyssié, Ross Jeffree, et al. Effects of ocean acidification on trace element accumulation in the early-life stages of squid Loligo vulgaris. Aquatic Toxicology, 2011, 105, pp.166-176. 10.1016/j.aquatox.2011.05.021 . hal-00785214

\section{HAL Id: hal-00785214 \\ https://hal.science/hal-00785214}

Submitted on 5 Feb 2013

HAL is a multi-disciplinary open access archive for the deposit and dissemination of scientific research documents, whether they are published or not. The documents may come from teaching and research institutions in France or abroad, or from public or private research centers.
L'archive ouverte pluridisciplinaire $\mathbf{H A L}$, est destinée au dépôt et à la diffusion de documents scientifiques de niveau recherche, publiés ou non, émanant des établissements d'enseignement et de recherche français ou étrangers, des laboratoires publics ou privés. 


\section{Effects of ocean acidification on trace element accumulation in the early-life stages of squid Loligo vulgaris}

Lacoue-Labarthe T. ${ }^{1,2}$, Réveillac E. ${ }^{3}$, Oberhänsli F. ${ }^{2}$, Teyssié J.-L. ${ }^{2}$, Jeffree, R. ${ }^{2,4}$, Gattuso J.P. ${ }^{1,5}$

1. INSU-CNRS, Laboratoire d'Océanographie de Villefranche, B.P. 28, 06234 Villefranchesur-mer Cedex, France

2. International Atomic Energy Agency - Environment Laboratories, 4 Quai Antoine Ier, MC-98000 Monaco, Principality of Monaco

3. Littoral, Environnement et Sociétés (LIENSs) UMR 6250 CNRS-Université de La Rochelle, Institut du Littoral et de l'Environnement, 2 rue Olympe de Gouges, F-17042 La Rochelle cedex 01, France

4. School of the Environment, Science Faculty, University of Technology Sydney, NSW, 2007, Australia.

5. Université Pierre et Marie Curie, Observatoire Océanologique de Villefranche, 06230 Villefranche-sur-mer, France

Correspondence to: T. Lacoue-Labarthe Present address:

IAEA-EL

Radioecology Laboratory

4 Quai Antoine Ier

MC- 98000 Monaco

E-mail: tlacouel@gmail.com 


\section{Abstract}

The anthropogenic release of carbon dioxide $\left(\mathrm{CO}_{2}\right)$ into the atmosphere leads to an increase in the $\mathrm{CO}_{2}$ partial pressure $\left(p \mathrm{CO}_{2}\right)$ in the ocean, which may reach $950 \mu$ atm by the end of the $21^{\text {st }}$ century. The resulting hypercapnia (high $p \mathrm{CO}_{2}$ ) and decreasing $\mathrm{pH}$ ("ocean acidification") are expected to have appreciable effects on water-breathing organisms, especially on their early-life stages. For organisms like squid that lay their eggs in coastal areas where the embryo and then paralarva are also exposed to metal contamination, there is a need for information on how ocean acidification may influence trace element bioaccumulation during their development. In this study, we investigated the effects of enhanced levels of $p \mathrm{CO}_{2}$ (380, 850 and $1500 \mu \mathrm{atm}$ corresponding to $\mathrm{pH}_{\mathrm{T}}$ of $8.1,7.85$ and 7.60) on the accumulation of dissolved ${ }^{110 \mathrm{~m}} \mathrm{Ag},{ }^{109} \mathrm{Cd},{ }^{57} \mathrm{Co},{ }^{203} \mathrm{Hg},{ }^{54} \mathrm{Mn}$ and ${ }^{65} \mathrm{Zn}$ radiotracers in the whole egg strand and in the different compartments of the egg of Loligo vulgaris during the embryonic development and also in hatchlings during their first days of paralarval life. Retention properties of the eggshell for ${ }^{110 \mathrm{~m}} \mathrm{Ag},{ }^{203} \mathrm{Hg}$ and ${ }^{65} \mathrm{Zn}$ were affected by the $p \mathrm{CO}_{2}$ treatments. In the embryo, increasing seawater $p \mathrm{CO}_{2}$ enhanced the uptake of both ${ }^{110 \mathrm{~m}} \mathrm{Ag}$ and ${ }^{65} \mathrm{Zn}$ while ${ }^{203} \mathrm{Hg}$ showed a minimum concentration factor $(\mathrm{CF})$ at the intermediate $p \mathrm{CO}_{2} \cdot{ }^{65} \mathrm{Zn}$ incorporation in statoliths also increased with increasing $p \mathrm{CO}_{2}$. Conversely, uptake of ${ }^{109} \mathrm{Cd}$ and ${ }^{54} \mathrm{Mn}$ in the embryo decreased as a function of increasing $p \mathrm{CO}_{2}$. Only the accumulation of ${ }^{57} \mathrm{Co}$ in embryos was not affected by increasing $p \mathrm{CO}_{2}$. In paralarvae, the $\mathrm{CF}$ of ${ }^{110 \mathrm{~m}} \mathrm{Ag}$ increased with increasing $p \mathrm{CO}_{2}$, whereas the ${ }^{57} \mathrm{Co} \mathrm{CF}$ was reduced at the highest $p \mathrm{CO}_{2}$ and ${ }^{203} \mathrm{Hg}$ showed a maximal uptake rate at the intermediate $p \mathrm{CO}_{2} \cdot{ }^{54} \mathrm{Mn}$ and ${ }^{65} \mathrm{Zn}$ accumulation in paralarvae were not significantly modified by hypercapnic conditions. Our results suggest a combined effect of $\mathrm{pH}$ on the adsorption and protective properties of the eggshell and of hypercapnia on the metabolism of embryo and paralarvae, both causing changes to the accumulation of metals in the tissues of L. vulgaris.

Keyword: cephalopod, metal, $\mathrm{CO}_{2}$, embryo, paralarvae, eggshell 


\section{Introduction}

Rising atmospheric carbon dioxide $\left(\mathrm{CO}_{2}\right)$ levels, driven by fossil fuel combustion, cement production and changing land use are generating major changes in the chemistry of seawater. The global atmospheric concentration of $\mathrm{CO}_{2}$ has increased from a pre-industrial value of approximately 280 ppmv to 379 ppmv in 2005 (IPCC, 2007) and is projected to further increase in the coming decades. It is expected to exceed 500 ppmv by year 2050 and could reach 950-1020 ppmv by the end of the century (Orr, in press). By air-sea equilibration, the uptake of anthropogenic $\mathrm{CO}_{2}$ by the oceanic surface waters is consecutively expected to increase (Sabine et al., 2004). This will cause major shifts in the ocean carbonate chemistry, i.e. increased concentrations of dissolved inorganic carbon and bicarbonate ions, decreased carbonate concentration, and $\mathrm{pH}$ is expected to decline by $0.2-0.4$ units, a phenomenon called “ocean acidification" (Caldeira and Wickett, 2005).

The consequences of ocean acidification for marine biota could be wide ranging. Calcification is certainly the process that has been investigated the most to date. The decrease in the availability of carbonate is expected to lead to reductions in the calcification rate of many organisms that precipitate shells and skeleton (e.g. Gattuso et al., 1998, 1999; Doney et al., 2009) and acidified seawater could become corrosive to these $\mathrm{CaCO}_{3}$ structures (Orr et al. 2005). Impacts of dissolved $\mathrm{CO}_{2}$ on the biology of water-breathers are known to alter survival rates (Talmage and Gobler, 2010), development (Kurihara, 2008; Dupont and Thorndyke, 2009), growth rate (Findlay et al., 2010), immune response (Bibby et al., 2008), feeding rate (Dupont and Thorndyke, 2009), sensory capacities (Munday et al., 2009) and metabolism (Lannig et al., 2010). Some of the physiological responses are considered to be consequences of ionic and acid-base balance disturbances (Deigweiher et al., 2008; Pörtner, 2008; Pörtner and Farrell, 2009). However, some organisms such as fish, crustacean, or echinoderms are not impaired by hypercapnia (high $p \mathrm{CO}_{2}$ ) or exhibit unexpected responses such as increased calcification or growth rates (e.g. Melzner et al., 2009; Dupont et al., 2010).

Cephalopods have been considered to be particularly vulnerable to ocean acidification due to peculiar aspects of their physiology. They are active coastal invertebrates (O'Dor and Webber, 1986) enabling them, especially squid, to compete with fish for similar ecological niches (Packard, 1972; Arkhipkin and Laptikhovsky, 2010). But, cephalopods' aerobic performance is sustained by the highly $\mathrm{pH}$-dependent affinity (i.e. Bohr effect) of their $\mathrm{O}_{2}$ carrying hemocyanin that delivers $\mathrm{O}_{2}$ to their tissues and cells (Bridges, 1994). Thus, changes in extra- and intracellular $\mathrm{pH}$ resulting from increasing environmental $p \mathrm{CO}_{2}$ are expected to 
have major impacts on the physiological performances of cephalopods (Pörtner and Zielinski, 1998; Pörtner, 2008). A recent report has revealed, however, that the cuttlefish, Sepia officinalis, exhibits both higher rates of growth and calcification at $6000 \mu$ atm of $p \mathrm{CO}_{2}$ (Gutowska et al., 2010a) and compensates for hypercapnia-induced extracellular acidosis with no significant increase in energy expenditure (Gutowska et al., 2010b). Nevertheless, invertebrate embryonic and larval stages are considered to be very sensitive in regard to ocean acidification (Dupont et al., 2010) while their respiratory system is still immature (Pörtner and Farrell, 2008). Moreover, cephalopods lay their eggs in shallow waters prior to their death (Worms, 1983) that results in their early-life stages being exposed to coastal metallic contamination. As changes in $\mathrm{pH}$ and carbonate chemistry are also predicted to alter the chemical speciation of trace elements, ocean acidification will possibly modify their bioavailability to marine biota (Byrne et al., 1988). Nowadays, there is little information on how the cephalopod early-life stages will respond to ocean acidification in combination with other stressors such as contaminants, that are predicted to also increase in coastal waters (Harley et al., 2006).

In cuttlefish, the eggshell surrounding the embryo acts as a protective barrier that limits or hinders the incorporation of metals into the organism during its initial developmental stages, and with a permeability that is element-specific (Bustamante et al., 2002, 2004, 2006; Lacoue-Labarthe et al., 2008). However, Lacoue-Labarthe et al. (2009a) observed that increased $p \mathrm{CO}_{2}$ strongly affects $\mathrm{Ag}, \mathrm{Cd}$ and $\mathrm{Zn}$ uptake in embryos, probably through $\mathrm{pH}$ induced changes in the permeability of the eggshell. Compared to quite large eggs of cuttlefish encapsulated in hard shells, small squid eggs (reduced in size by 1 order of magnitude) enveloped in a soft and gelatinous shell produce active swimming hatchlings (Boletzky, 1986, Nixon and Mangold, 1998), and, as recently observed, showed higher metal bioaccumulation capacities (Lacoue-Labarthe et al., sbm). Such differences in egg structure may well modify the effects that ocean acidification would have on trace elements uptake in the early-life stages of squid. To test this hypothesis, this radiotracer study determined the effect of hypercapnia on the accumulation biokinetics and distribution of ${ }^{110 \mathrm{~m}} \mathrm{Ag},{ }^{109} \mathrm{Cd},{ }^{57} \mathrm{Co}$, ${ }^{203} \mathrm{Hg},{ }^{54} \mathrm{Mn}$ and ${ }^{65} \mathrm{Zn}$ in the early-life stages of L. vulgaris that encompassed the developmental phases from the newly spawned encapsulated embryos through to the 52 hours eggshell-free "paralarvae".

\section{Materials and Methods}


1. Organisms, radiotracers and experimental procedures

\section{Egg strand experiment}

Egg masses of the squid Loligo vulgaris (1-2 d post spawning) were netted at 50 to $200 \mathrm{~m}$ water depth in front of Monaco in June 2009. These egg strands $(n=30)$ were immediately separated and haphazardly assigned to three 51 plastic bottles (one bottle per treatment) filled with filtered $(0.45 \mu \mathrm{m})$ and UV-sterilized Mediterranean seawater. Seawater was constantly aerated and the light:dark cycle was 12:12. Eggs were maintained under regulated conditions of $\mathrm{pH}$ : one bottle was maintained at ambient $\mathrm{pH}_{\mathrm{T}}\left(8.10 ; \mathrm{pH}_{\mathrm{T}}\right.$ is the $\mathrm{pH}$ expressed on the total scale) whereas the other two were maintained at two $\mathrm{pH}_{\mathrm{T}}$ levels (7.85 and 7.60). The $\mathrm{pH}_{\mathrm{T}}$ levels were chosen according to values predicted to occur by the end of this century according to various scenarios for the trajectories of carbon emissions [(Orr et al., 2005: $7.85\left(p \mathrm{CO}_{2}=\right.$ $\left.850 \mu \mathrm{atm}), 7.60\left(p \mathrm{CO}_{2}=1500 \mu \mathrm{atm}\right)\right]$. Once stable $\mathrm{pH}$ was reached (see below), radiotracers were added to each bottle and the trace metal uptake kinetics were determined, as described below. Seawater was renewed daily with sterilized, filtered and $\mathrm{pH}$-adjusted Mediterranean seawater during the first three days and then every second or third day in order to maintain good water quality and radiotracers concentrations as constant as possible. Bottles were changed and cleaned at each seawater renewal to prevent any "bottle" effect due to the development of different biomasses due to the accumulation of detritus such as fragments of eggshell layers, or due to bacterial proliferation, which could affect the metabolism of eggs or the bioavailability of trace elements.

\section{Paralarvae experiment}

Egg strands $(n=15)$ from the initial egg masses were maintained under controlled conditions until the first larvae hatched. At this time, egg strands were placed in 51 bottles filled with filtered and sterilized seawater and controlled $\mathrm{pH}$ until an adequate number of paralarvae for the experiment were obtained, i.e. 100 for each experimental condition. Radiotracers were then introduced into each bottle and the metal uptake kinetics were monitored during $52 \mathrm{~d}$, as described below.

\section{$\mathrm{CO}_{2}$ incubations}

Water bottle $\mathrm{pH}$ values were maintained within \pm 0.05 unit with a $\mathrm{pH}$-stat system (IKS, Karlsbad) that added pure $\mathrm{CO}_{2}$ into the bottles that were continuously aerated with $\mathrm{CO}_{2}$-free 
air. The $\mathrm{pH}_{\mathrm{NBS}}$ (National Bureau of Standard scale) values were logged every $10 \mathrm{~min}$ and were converted from the NBS scale to the total scale $\left(\mathrm{pH}_{\mathrm{T}}\right)$ using point $\mathrm{pH}$ measurements on both scales performed every 2 days. The $\mathrm{pH}$ values were measured using a $\mathrm{pH}$ meter (Metrohm, $826 \mathrm{pH}$ mobile) with a glass electrode (Metrohm, electrode plus) that was calibrated on the total scale using $\mathrm{Tris} / \mathrm{HCl}$ and 2-aminopyridine $/ \mathrm{HCl}$ buffer solutions with a salinity of 38 and prepared according to Dickson et al. (2007). Total alkalinity (TA) changes between two seawater renewals were assessed in a control (i.e. radiotracers-free) bottle containing similar egg strand masses or the same number of paralarvae and maintained at ambient $\mathrm{pH}_{\mathrm{T}}(\mathrm{ca} .8 .1)$ and temperature $\left(16^{\circ} \mathrm{C}\right)$. TA was measured on seawater samples filtered through $0.45 \mu \mathrm{m}$ membranes that were immediately poisoned with mercuric chloride and stored in a cool dark place pending analysis. Seawater was sampled just before and after seawater renewal. TA was determined potentiometrically using a home-made titration system with an Orion 8103SC pH electrode calibrated on the NBS scale and a computer-driven Metrohm 665 Dosimat titrator. TA was calculated using a Gran function applied to $\mathrm{pH}$ values ranging from 3.5 to 3.0 as described by Dickson et al. (2007). The $p \mathrm{CO}_{2}$ was determined from $\mathrm{pH}_{\mathrm{T}}$ and total alkalinity using the $\mathrm{R}$ package seacarb (Lavigne and Gattuso, 2010).

\section{Radiotracers exposure}

Water bottles were spiked with radioactive ${ }^{110 \mathrm{~m}} \mathrm{Ag}\left(1 \mathrm{kBq} 1^{-1}\right),{ }^{109} \mathrm{Cd}\left(1.5 \mathrm{kBq}^{-1}\right),{ }^{57} \mathrm{Co}(1 \mathrm{kBq}$ $\left.\mathrm{l}^{-1}\right),{ }^{203} \mathrm{Hg}\left(1 \mathrm{kBq}{ }^{-1}\right),{ }^{54} \mathrm{Mn}\left(1 \mathrm{kBq} \mathrm{l^{-1 }}\right)$ and ${ }^{65} \mathrm{Zn}\left(1 \mathrm{kBq} \mathrm{l^{-1 }}\right)$. These activities corresponded to an addition of 14, 11, 92 and $0.9 \mathrm{pmol} \mathrm{L}^{-1}$ of $\mathrm{Ag}, \mathrm{Cd}, \mathrm{Co}$ and $\mathrm{Zn}$, respectively, to the natural concentrations present in the filtered Mediterranean seawater. Specific activities of ${ }^{54} \mathrm{Mn}$ and ${ }^{203} \mathrm{Hg}$ sources were not available according to the provider. These additions of metals per spike were one to five orders of magnitude lower than the natural concentrations of metals reported in seawater (Bruland, 1983). Radiotracers were purchased from Amersham, UK $\left({ }^{110 \mathrm{~m}} \mathrm{Ag},{ }^{109} \mathrm{Cd}\right.$ and $\left.{ }^{57} \mathrm{Co}\right)$ and Isotope Product Laboratory, USA $\left({ }^{54} \mathrm{Mn}\right.$ and $\left.{ }^{65} \mathrm{Zn}\right):{ }^{110 \mathrm{~m}} \mathrm{Ag}$ [as $\left.{ }^{110 \mathrm{~m}} \mathrm{AgNO}_{3} ; \mathrm{T}^{1 / 2}=250 \mathrm{~d}\right],{ }^{109} \mathrm{Cd}$ as ${ }^{109} \mathrm{CdCl}_{2} ; \mathrm{T}^{1} / 2=464 \mathrm{~d}$ ], ${ }^{57} \mathrm{Co}\left[\right.$ as ${ }^{57} \mathrm{CoCl}_{2} ; \mathrm{T}^{1 / 2}=272 \mathrm{~d}$ ], ${ }^{203} \mathrm{Hg}$ [as ${ }^{203} \mathrm{HgCl}_{2} ; \mathrm{T}^{1 / 2}=46.6 \mathrm{~d}$ ], ${ }^{54} \mathrm{Mn}$ [as ${ }^{54} \mathrm{MnCl}_{2} ; \mathrm{T}^{1 / 2}=312 \mathrm{~d}$ ] and ${ }^{65} \mathrm{Zn}$ [as ${ }^{65} \mathrm{ZnCl}_{2} ; \mathrm{T}^{1 / 2}=$ $244 \mathrm{~d}$ ]. Stock solutions were prepared in $0.1 \mathrm{~N}$ nitric acid $\left({ }^{110 \mathrm{~m}} \mathrm{Ag}\right)$, in $0.1 \mathrm{~N}$ chloridric acid $\left({ }^{109} \mathrm{Cd},{ }^{57} \mathrm{Co},{ }^{54} \mathrm{Mn}\right.$ and ${ }^{65} \mathrm{Zn}$, respectively) and in $\mathrm{H}_{2} \mathrm{O}\left({ }^{203} \mathrm{Hg}\right)$. Spikes volume was typically 5 $\mu \mathrm{L}$.

For each treatment, radiotracers spikes were renewed after each water renewal, i.e. daily, during the first three days and then every second or third day to maintain radiotracer concentrations as stable as possible. Radiotracers activities in seawater were checked before 
and after each water renewal in order to determine the time-integrated radiotracers activities, i.e. the mean value of all measurements performed over the time period considered (Metian et al., 2009).

Egg experiment: at different time intervals the six radionuclides activities were counted in the same 4 labelled egg strands per bottle during the total experimental exposure. After $16 \mathrm{~d}$ and $26 \mathrm{~d}$ of development (respectively at stage 25-26 and 29-30), 3 additional egg strands from each experimental condition were counted and dissected to determine the radiotracer distribution among the external (i.e. nidamental eggshell) and internal (i.e. oviducal eggshell including the chorion) eggshell parts, the vitellus, the embryo and the perivitelline fluid. Statoliths were removed from pre-hatched embryos (26 d) and pooled for activity measurement according to their rearing conditions $(n=95,126$ and 115 at 1500, 850 and 380 $\mu$ atm, respectively). Additionally, statoliths of late-stage embryos that had been maintained at the same $p \mathrm{CO}_{2}$ treatments, but not exposed to radiotracers, were extracted for surface area measurement using Image ${ }^{\circledR}$ software. These measurements provided an estimate of their size at the end of development in each treatment $(n=21,22$ and 15 at 1500,850 and $380 \mu \mathrm{atm}$, respectively).

Paralarvae experiment: 5 groups of paralarvae $(n=5-10$ in order to facilitate radiotracer activities detection) were sampled from each $p \mathrm{CO}_{2}$ condition after 6,28 and $52 \mathrm{~h}$ of exposure, rapidly rinsed with unlabelled seawater, weighted and counted as described below.

\section{Radioanalyses and data treatments}

Radioactivities were measured using a high-resolution $\gamma$-spectrometry system consisting of four coaxial Germanium (N- or P-type) detectors (EGNC 33-195-R, Canberra ${ }^{\circledR}$ and Eurysis $\left.{ }^{\circledR}\right)$ connected to a multi-channel analyzer and a computer equipped with a spectra analysis software (Interwinner ${ }^{\circledR}$ 6). The detectors were calibrated with an appropriate standard for each counting geometry that was used and measurements were corrected for background and physical decay of the radiotracers. Counting times were adapted to obtain relative propagated errors less than 5\%. They ranged from 10 to $30 \mathrm{~min}$ for whole eggs and from $10 \mathrm{~min}$ to $24 \mathrm{~h}$ for the dissected egg compartments.

Uptake of ${ }^{110 \mathrm{~m}} \mathrm{Ag},{ }^{109} \mathrm{Cd},{ }^{57} \mathrm{Co},{ }^{203} \mathrm{Hg},{ }^{54} \mathrm{Mn}$ and ${ }^{65} \mathrm{Zn}$ was expressed as changes in concentration factors $(\mathrm{CF})$, which is the ratio between radiotracer activity in the egg strand, egg compartment or paralarvae $\left(\mathrm{Bq} \mathrm{g}^{-1}\right)$ and the time-integrated activity in seawater $\left(\mathrm{Bq} \mathrm{g}^{-1}\right.$; Metian et al., 2009). This unit-less term expresses the efficiency of an organism (or a 
biological compartment) to accumulate and concentrate an element from seawater after a fixed time of exposure.

Uptake kinetics were best described using either a linear equation (Eq. 1), a saturation exponential equation (Eq. 2), or a combined equation (exponential and linear) (Eq. 3):

$\mathrm{CF}_{\mathrm{t}}=\mathrm{k}_{\mathrm{u}} \mathrm{t}$

$\mathrm{CF}_{\mathrm{t}}=\mathrm{CF}_{\mathrm{ss}}\left(1-\mathrm{e}^{-\mathrm{ke} t}\right)$

$\mathrm{CF}_{\mathrm{t}}=\mathrm{CF}_{\mathrm{ss}}\left(1-\mathrm{e}^{-\mathrm{ke} 1 \mathrm{t}}\right)+\mathrm{k}_{\mathrm{u} 2} \mathrm{t}$ with $\mathrm{CF}_{\mathrm{ss}}=\mathrm{k}_{\mathrm{u} 1} / \mathrm{k}_{\mathrm{e} 1}$

where $\mathrm{CF}_{\mathrm{t}}$ and $\mathrm{CF}_{\mathrm{ss}}$ are the concentration factors at time $\mathrm{t}(\mathrm{d})$ and at steady-state, and $\mathrm{k}_{\mathrm{e}}$ and $\mathrm{k}_{\mathrm{u}}$ are the biological depuration and uptake rate constants $\left(\mathrm{d}^{-1}\right)$ (Whicker and Schultz, 1982).

Constants for the best fitting uptake kinetic equations (decision based on ANOVA tables for two fitted model objects) as well as their statistics of variability were estimated by iterative adjustment of the models using the nls or $1 \mathrm{~m}$ curve-fitting routine in $\mathrm{R}$ ( $\mathrm{R}$ Development Core Team, 2008). F-tests were used to determine whether $p \mathrm{CO}_{2}$ exposure influenced the uptake rate $\left(\mathrm{k}_{\mathrm{u}}\right)$ of radiotracers or the $\mathrm{CF}_{\mathrm{ss}}$ reached at the steady-state equilibrium. A Kruskal-Wallis test was applied to determine the differences in the radiotracers CF reached in embryo and eggshell at the late embryonic stages (stage 29-30) among the different $p \mathrm{CO}_{2}$ treatments. The level of significance for statistical analyses was always set at $\alpha=0.05$. Results are reported as means \pm s.d.

\section{Results}

1. Carbonate chemistry during the incubations

During embryonic development, $\mathrm{pH}_{\mathrm{T}}$ was maintained at $7.57 \pm 0.03,7.79 \pm 0.05$, and $8.08 \pm$ 0.04 at a temperature of $16.1 \pm 0.4^{\circ} \mathrm{C}$. Mean TA of renewed seawater was $2.521 \pm 0.005$ mmol kg-1 (range of 2.512 to $2.528 \mathrm{mmol} \mathrm{kg}^{-1}$ ). It changed by 0.005 to $0.050 \mathrm{mmol} \mathrm{\textrm {kg } ^ { - 1 }}$ between two seawater renewals (TA range of 2497 to $2575 \mathrm{mmol} \mathrm{kg}^{-1}$ ). These conditions correspond to the following ranges of $p \mathrm{CO}_{2} ; 1470$ to 1507,846 to 868 and 392 to $401 \mu \mathrm{atm}$, respectively in the three treatments. Squid paralarvae were maintained at $\mathrm{pH}_{\mathrm{T}} 7.55 \pm 0.02$, $7.90 \pm 0.02$ and $8.12 \pm 0.02$ at a temperature of $15.8 \pm 0.3^{\circ} \mathrm{C}$. The mean TA of renewed seawater was $2.526 \pm 0.003 \mathrm{mmol} \mathrm{kg}^{-1}$. It changed by 0.095 to $0.105 \mathrm{mmol} \mathrm{kg}^{-1}$ between two seawater renewals. These conditions correspond to ranges of $p \mathrm{CO}_{2}$ of 1550 to $1613 \mu \mathrm{atm}, 639$ to $666 \mu \mathrm{atm}$ and 353 to $368 \mu \mathrm{atm}$, respectively in the three treatments. 
2. Uptake kinetics in the egg strands and embryos

The uptake kinetics in whole egg strands showed contrasting patterns among radiotracers (Fig. 1; Table 1). Accumulation of ${ }^{109} \mathrm{Cd},{ }^{203} \mathrm{Hg},{ }^{54} \mathrm{Mn}$ and ${ }^{65} \mathrm{Zn}$ were best fitted by a saturation exponential model at every $p \mathrm{CO}_{2}$ levels. At steady state equilibrium, $\mathrm{CF}_{\mathrm{ss}}$ of ${ }^{109} \mathrm{Cd},{ }^{54} \mathrm{Mn}$ and ${ }^{65} \mathrm{Zn}$ were significantly lower at $p \mathrm{CO}_{2} 850$ and $1500 \mu \mathrm{atm}$ than at $380 \mu \mathrm{atm}\left({ }^{109} \mathrm{Cd} \mathrm{CF}_{\mathrm{ss}}: 37 \pm\right.$ 4 and $29 \pm 2<77 \pm 5 ;{ }^{54} \mathrm{Mn} \mathrm{CF}_{\mathrm{ss}}: 50 \pm 3$ and $78 \pm 6<113 \pm 5 ;{ }^{65} \mathrm{Zn} \mathrm{CF}_{\mathrm{ss}}: 201 \pm 18$ and $208 \pm$ $10<299 \pm 16$ at 850 and $1500<380 \mu \mathrm{atm}$, respectively). Surprisingly, ${ }^{203} \mathrm{Hg}$ uptake efficiency was maximal at the $850 \mu \mathrm{atm}\left({ }^{203} \mathrm{Hg} \mathrm{CF}_{\mathrm{ss}}: 371 \pm 9>334 \pm 8\right.$ and $292 \pm 8$ at $p \mathrm{CO}_{2}$ $850>1500$ and $380 \mu \mathrm{atm}$, respectively). For each of the $p \mathrm{CO}_{2}$ conditions, ${ }^{110 \mathrm{~m}} \mathrm{Ag}$ accumulation showed a two-step process (exponential + linear combined equation) with a rapid adsorption and/or absorption (e.g. $\mathrm{k}_{\mathrm{u} 1}=40 \mathrm{~d}^{-1}$ at $\left.380 \mu \mathrm{atm}\right)$ followed by a slower uptake phase $\left(e . g . \mathrm{k}_{\mathrm{u} 2}=0.05 \mathrm{~d}^{-1}\right.$ at $\left.380 \mu \mathrm{atm}\right)$. Whereas $p \mathrm{CO}_{2}$ did not influence $\mathrm{k}_{\mathrm{u} 1}$, higher $\mathrm{k}_{\mathrm{u} 2}$ was observed at $850 \mu \mathrm{atm},\left(0.08 \mathrm{~d}^{-1}\right.$ at $850 \mu \mathrm{atm}>0.05 \mathrm{~d}^{-1}$ at 380 and $\left.1500 \mu \mathrm{atm}\right)$, indicating that only the second $\mathrm{Ag}$ binding process was influenced by $\mathrm{pCO}_{2}$. Finally, ${ }^{57} \mathrm{Co}$ displayed linear kinetics and the uptake rates were unaffected by $p \mathrm{CO}_{2}\left(\mathrm{k}_{\mathrm{u}}: 4.98,4.95,4.49 \mathrm{~d}^{-1}\right.$ at 380,850 and $1500 \mu \mathrm{atm}$, respectively; $\mathrm{p}>0.05)$. Accumulation of this element in the squid egg masses was therefore at a constant linear rate.

With regard to the CF's in the squid embryo that developed under different $p \mathrm{CO}_{2}$ conditions (Fig. 2), and at two periods of development, the accumulation of ${ }^{110 \mathrm{~m}} \mathrm{Ag}$ was significantly higher at the highest $p \mathrm{CO}_{2}$ level than at the two lower exposure levels, irrespective of the development time (i.e. after 16 and $26 \mathrm{~d}$ of development). Similarly, the lower the seawater $\mathrm{pH}$, the more that ${ }^{65} \mathrm{Zn}$ was accumulated in the tissues of embryos at the end of their development, with ${ }^{65} \mathrm{Zn}$ CFs that were 1.2- and 1.4-fold higher at $\mathrm{pH}_{\mathrm{T}} 7.85$ and 7.60 than at normal $\mathrm{pH}_{\mathrm{T}}$, respectively. This result contrasts with the maximal ${ }^{65} \mathrm{Zn} \mathrm{CF}$ values in the embryo at $16 \mathrm{~d}$ at $\mathrm{pH}_{\mathrm{T}}$ 7.85. In contrast, the ${ }^{109} \mathrm{Cd}$ and ${ }^{54} \mathrm{Mn} \mathrm{CFs}$ in the embryo were reduced by decreasing $\mathrm{pH}_{\mathrm{T}}$. No significant effect of $\mathrm{pCO}_{2}$ was observed on ${ }^{57} \mathrm{Co}$ uptake. Nevertheless, the ${ }^{57} \mathrm{Co}$ concentration factor was very variable at the end of development $\left(\mathrm{CF}_{\mathrm{Co}}=317 \pm 377\right)$ in embryos that had been maintained under control $p \mathrm{CO}_{2}$ level (see details below, section 3). Finally, the ${ }^{203} \mathrm{Hg} \mathrm{CF}$ was lowest at $\mathrm{pH}_{\mathrm{T}} 7.85$ in embryos that were sampled a few hours before hatching, whereas no $p \mathrm{CO}_{2}$-effect on ${ }^{203} \mathrm{Hg}$ accumulation was observed after $16 \mathrm{~d}$ of embryonic development.

3. Radiotracers distribution and uptake in egg strand compartments 
Radiotracer distributions among different egg compartments at the end of development (Table 2) show that $p \mathrm{CO}_{2}$ had little effect for $\mathrm{Cd}, \mathrm{Co}, \mathrm{Hg}$ and $\mathrm{Mn}$, which remained mainly associated ( $>90 \%$ of the total amount) with the eggshell. More precisely, ${ }^{54} \mathrm{Mn},{ }^{203} \mathrm{Hg}$, and, to a lesser extent, ${ }^{109} \mathrm{Cd}$ were mainly bound to the external layers of the eggshell (Table $2 ; 92 \%, 80 \%$ and $55 \%$ at normal $\mathrm{pH}$, respectively) which is composed of the secretions of the nidamental gland. Whole eggshell $\mathrm{CF}$ values for ${ }^{109} \mathrm{Cd}$ and ${ }^{54} \mathrm{Mn}$ decreased with increasing $p \mathrm{CO}_{2}$, whereas the highest ${ }^{203} \mathrm{Hg} \mathrm{CF}$ in eggshell was found at a $p \mathrm{CO}_{2} 850 \mu \mathrm{atm}$, a $\mathrm{CO}_{2}$ level where the $\mathrm{Hg}$ concentration in the embryos was the lowest.

Interestingly, ${ }^{57} \mathrm{Co}$ was predominantly found in the internal eggshell parts, although it also showed high standard deviation values. Actually, in one of the three egg strands analyzed, an 8-fold higher Co accumulation in embryos was noted $\left(\mathrm{CF}_{\mathrm{Co}}=834 \pm 142\right.$ vs. $\left.104 \pm 84\right)$. This was associated with a CF value in the internal eggshell layers that was 4.5 -fold lower compared to the concentration found in the other egg strands $\left(\mathrm{CF}_{\mathrm{Co}}=83 \pm 18\right.$ vs. $\left.386 \pm 53\right)$. This result suggests a failure in the Co retention capacities of the internal shells and therefore in the protective role of the chorion against Co penetration.

The proportion of ${ }^{110 \mathrm{~m}} \mathrm{Ag}$ and ${ }^{65} \mathrm{Zn}$ detected in the eggshell was reduced between the normal and the highest $p \mathrm{CO}_{2}$, from $55 \%$ to $37 \%$ and from $90 \%$ to $70 \%$, respectively whereas it increased in the embryo from $45 \%$ to $62 \%$ and from $10 \%$ to $30 \%$, respectively. These distributions match with the maximum ${ }^{110 \mathrm{~m}} \mathrm{Ag} \mathrm{CF}$ value found at $800 \mu \mathrm{atm}\left(\mathrm{pH}_{\mathrm{T}} 7.85\right)$ and the decrease of the ${ }^{65} \mathrm{Zn}$ accumulation in the eggshell with increasing $p \mathrm{CO}_{2}\left({ }^{110 \mathrm{~m}} \mathrm{Ag} \mathrm{CF}: 425 \pm\right.$ $102>255 \pm 74>187 \pm 58$, i.e. $\mathrm{CF}_{7.85}>\mathrm{CF}_{8.10}>\mathrm{CF}_{7.60}$ and ${ }^{65} \mathrm{Zn}: \mathrm{CF}_{8.10} \approx \mathrm{CF}_{7.85}>\mathrm{CF}_{7.60}$ ) occurring concomitantly with the increase of the metal uptake efficiency in the embryo (Table 2; see section 2 above). These results suggest, as observed for ${ }^{203} \mathrm{Hg}$, that the less the metals were accumulated/retained by the eggshell with increasing $p \mathrm{CO}_{2}$, the more they were found in the embryos contained within.

\section{Zn accumulation in embryo statoliths}

Only ${ }^{65} \mathrm{Zn}$ accumulated to a detectable degree in the statoliths of embryos that were sampled and pooled for analysis at the end of the developmental phase. Its load concentration ratio $\left(\mathrm{LCR}_{\mathrm{st}}\right.$ in $\mathrm{g}$, corresponding to the activity in one statolith $(\mathrm{Bq})$ normalized by the activity in seawater (Bq.ml ${ }^{-1}$ ); Lacoue-Labarthe et al., 2008) followed a trend similar to that observed in the whole body of the embryo. It increased with increasing $p \mathrm{CO}_{2}$, i.e. $2.68 \times 10^{-3} \mathrm{~g}, 3.10 \times 10^{-}$ ${ }^{3} \mathrm{~g}$ and $3.93 \times 10^{-3} \mathrm{~g}$ at 380,850 and $1500 \mu \mathrm{atm}$, respectively. Moreover, the statoliths were significantly bigger when embryos developed at $1500 \mu \mathrm{atm}$ and $850 \mu \mathrm{atm}$ compared to 380 
$\mu$ atm with mean surface areas of $14.27 \pm 1.06 \mathrm{~mm}^{2}$ and $14.53 \pm 0.67 \mathrm{~mm}^{2}$ against $12.91 \pm$ $0.59 \mathrm{~mm}^{2}$, respectively (ANOVA, $\mathrm{p}<0.001$ ). However, the mantle length of embryos did not vary significantly between treatments $(2.51 \pm 0.07 \mathrm{~mm}, 2.56 \pm 0.07 \mathrm{~mm}$ and $2.50 \pm 0.05 \mathrm{~mm}$ at 1500, 800 and $380 \mu \mathrm{atm}$, respectively; ANOVA, $\mathrm{p}>0.05)$.

5. Uptake kinetics of tracers in the three first days of "paralarval" life

Despite the relatively short experimental exposure $(52 \mathrm{~h})$, the ${ }^{110 \mathrm{~m}} \mathrm{Ag}$ and ${ }^{60} \mathrm{Co}$ uptake kinetics were best described by a saturation exponential model $\left(\mathrm{R}^{2}=0.81\right)$, whereas ${ }^{203} \mathrm{Hg}$, ${ }^{54} \mathrm{Mn}$ and ${ }^{65} \mathrm{Zn}$ kinetics were best fitted by a linear model $\left(\mathrm{R}^{2}=0.90\right)($ Fig. 3, Table 2$)$. The ${ }^{109} \mathrm{Cd}$ uptake kinetic was not established as recorded activities were below the limit of detection. As found in the embryo, the lower the $\mathrm{pH}$, the higher ${ }^{110 \mathrm{~m}} \mathrm{Ag} \mathrm{CF}_{\mathrm{ss}}$ accumulation was in the paralarvae, with $\mathrm{CF}_{\mathrm{ss}-7.60}$ and $\mathrm{CF}_{\mathrm{ss}-7.85}$ that were 1.8- and 1.4-fold higher than $\mathrm{CF}_{\mathrm{ss}-}$ 8.10. In contrast, ${ }^{60} \mathrm{Co} \mathrm{CF}_{\mathrm{ss}}$ was significantly lower at $\mathrm{pH}_{\mathrm{T}} 7.60$ compared to intermediate and control pHs (Table 2). Similarly to the previous observations on the egg strand, the ${ }^{203} \mathrm{Hg}$ uptake kinetics was enhanced at $\mathrm{pH}_{\mathrm{T}} 7.85$ with higher uptake rate constant compared to those at $\mathrm{pH}_{\mathrm{T}} 8.10$ and 7.60 (Table 2). No significant $\mathrm{pH}$ effect was observed on the uptake rate of ${ }^{54} \mathrm{Mn}$ and ${ }^{65} \mathrm{Zn}$, but ${ }^{65} \mathrm{Zn} \mathrm{CF}_{7.85}$ reached at the end of exposure time was significantly higher than $\mathrm{CF}_{7.60}$ (Kruskal-Wallis test, $\mathrm{p}<0.05$ ). Similarly, ${ }^{54} \mathrm{Mn} \mathrm{CF}_{7.60}$ was significantly lower than $\mathrm{CF}_{8.10}$ after $52 \mathrm{~h}$ of exposure (Kruskall-Wallis test: $\mathrm{p}<0.01$ ), suggesting that increasing $p \mathrm{CO}_{2}$ could limit the $\mathrm{Mn}$ accumulation in the paralarvae.

\section{Discussion}

Squid egg strand is characterized by a complex structure in which several small oocytes surrounded by a chorion are united by oviducal jelly, and enveloped by a common sheet of nidamental secretions (Boletzky et al., 1986). As in cuttlefish eggs, some structural changes occur during the embryonic development. The volume, the surface and the weight of the egg strand increase throughout development as a consequence of the swelling (massive entry of water through the eggshell) of the numerous eggs embedded in the same cluster. In cuttlefish eggs, it has been demonstrated that the increased permeability of the egg to some metals is correlated with this swelling process (Lacoue-Labarthe et al., 2008, 2010). In the present study, the uptake of radiotracers in the whole egg strand was expressed in terms of metal concentration factor (CF). The trace elements accumulation was therefore under- 
estimated by the rising egg weight that in turn led to a dilution effect (Lacoue-Labarthe et al., 2008). Data were nevertheless expressed in terms of CF so as to compare results obtained on egg strands that were highly variable in terms of length and number of eggs embedded inside.

The effect of acidity on metal toxicity has been well documented, especially in freshwater organisms (e.g. Wood, 1992; Carvahlo and Fernandes, 2006). However, to the best of our knowledge, few studies have investigated the impact of increased $p \mathrm{CO}_{2}$ on metals accumulation and effects on marine organisms (Lacoue-Labarthe et al., 2009a, Pascal et al., 2010). Two aspects of the combined impacts of hypercapnia and metal toxicity on waterbreathing animals must be considered. On the one hand, the speciation and, subsequently the bioavailability of metals that form strong complexes with hydroxide and carbonate ions (Byrne, 2002), both of which being expected to decrease in seawater (Feely et al., 2004), might be affected (Shi et al., 2010). Moreover, the increase in the concentration of $\mathrm{H}^{+}$could lead to a competition between protons and cationic metals for the binding sites on the biological surface (Millero et al., 2009). On the other hand, seawater $p \mathrm{CO}_{2}$ might impair the acid-base balance and ion regulation (e.g. Pörtner, 2008) and hence disturb active transport or passive diffusion of metals through epithelial membrane (e.g. Rainbow, 1997a) and therefore accumulation in tissues.

In a previous study carried out in similar experimental conditions (Lacoue-Labarthe et al., 2009a), speciation modelling has shown that decreased $\mathrm{pH}_{\mathrm{T}}$ from 8.10 to 7.60 had a very minor effect on the speciation of $\mathrm{Ag}, \mathrm{Cd}$ or $\mathrm{Zn}$ and their concentration as free metal ions, i.e. the bioavailable form of metals, in this experimental water. Through modeling, Millero et al. (2009) showed that metals forming strong chloride complexes (e.g. $\mathrm{Ag}, \mathrm{Cd}$ and $\mathrm{Hg}$ ) are not affected by decreased $\mathrm{pH}$. Moreover, the predominant free form for $\mathrm{Co}, \mathrm{Mn}$ and $\mathrm{Zn}$ increased by only a few percent $(4 \%, 2 \%$ and $13 \%$, respectively) with decreasing $\mathrm{pH}$. Consequently, any observed effect of $\mathrm{pH}$ on the accumulation of these six trace elements by squid early-life stages can be regarded as predominantly due to responses of the exposed tissues and/or competition with elevated $\left[\mathrm{H}^{+}\right]$at the cell surface binding sites.

The changes in whole egg metal uptake kinetics with increasing $p \mathrm{CO}_{2}$ (Fig. 1) can be regarded as an effect of $\mathrm{pH}$ on the metal accumulation in the eggshell. As already reported, most of metals ( $>90 \%$ of the total amount except for $\mathrm{Ag} \sim 50 \%$ ) is found associated with the eggshell (Lacoue-Labarthe et al., 2008, 2010). This is likely because of the presence of metal binding carboxyl- and sulfhydryl-rich groups (e.g. Rainbow, 1997b) in the mucine-rich egg 
surface layers (Boletzky et al., 1986). Under acidified conditions, the lowered ${ }^{109} \mathrm{Cd},{ }^{54} \mathrm{Mn}$ and ${ }^{65} \mathrm{Zn} \mathrm{CF}_{\mathrm{ss}}$ values in the egg strands (Fig. 1) and in the eggshell (Table 2) suggest that these "Class Borderline" elements, i.e. metals exhibiting equal binding-affinity for O or S (Nieboer and Richardson, 1980), are subjected to increased competition with protons for the adsorption on binding sites located on the external eggshell surface. At $\mathrm{pH}_{\mathrm{T}} 7.85$, the highest ${ }^{110 \mathrm{~m}} \mathrm{Ag}$ uptake rate and ${ }^{203} \mathrm{Hg} \mathrm{CF}$ ss in egg strand coincide with the maximal accumulation of both metals in the eggshell (Table 2). Ag and Hg are "Class B" elements, i.e. with a strong affinity for the sulfhydryl groups, suggesting that $p \mathrm{CO}_{2}$ at $850 \mu$ atm enhanced the binding capacities of the eggshell components for these elements. So it can be hypothesized that ocean acidification affects the metal accumulation in both the eggshell and whole egg strands as a result of competition with $\mathrm{H}^{+}$for binding sites to a degree that is dependent on the chemical properties of trace element (Nieboer and Richardson, 1980). Moreover, it should be also pointed out that, in cephalopods, the symbiotic bacterial population embedded in the eggshell nidamental layers (Barbieri et al., 1997) could interfere with the uptake of metals. So far, all the mechanisms involved in the metal accumulation patterns of the eggshell under different $\mathrm{pH}$ are not fully understood nor quantified. However, this study clearly shows that elevated $p \mathrm{CO}_{2}$ modifies the metal binding and retention properties of the eggshell and could therefore affect its shielding properties regarding metal accumulation in embryos (Lacoue-Labarthe et al., 2008, 2009a).

Indeed, the observed metal CFs in the late stage embryo at different $\mathrm{pH}_{\mathrm{T}}$ values (Fig. 2) raise the question of the effect of $p \mathrm{CO}_{2}$ on the protective role of the eggshell and/or on the embryo metabolism that both could modulate the metal uptake in the organism. In this study, two distinct patterns have been found when comparing the metal accumulation in embryo and eggshell at various $p \mathrm{CO}_{2}$ levels: i) the uptake of ${ }^{109} \mathrm{Cd}$ and ${ }^{54} \mathrm{Mn}$ in the embryo decreased together with the reduced concentration in the eggshell with increasing $p \mathrm{CO}_{2}$. In contrast, ii) the more the ${ }^{110 \mathrm{~m}} \mathrm{Ag},{ }^{203} \mathrm{Hg}$ and ${ }^{65} \mathrm{Zn}$ (including also ${ }^{57} \mathrm{Co}$; see below) accumulated in the eggshell compartment, the lower were the CF values in the embryo.

First, the $\mathrm{Cd}$ and $\mathrm{Mn}$ showed a limited bioaccumulation in the embryo with increasing $p \mathrm{CO}_{2}$. In the cephalopod egg, large gradients of partial pressure of $\mathrm{O}_{2}$ and $\mathrm{CO}_{2}$ across the eggshell are necessary to drive gas exchanges between seawater and the PVF (Cronin and Seymour, 2000), which leads to a progressive decrease of $p \mathrm{O}_{2}$ and increase of $p \mathrm{CO}_{2}$ in the PVF along with the growth of the embryo (Gutowska and Melzner, 2009). Under acidified conditions, the $\mathrm{CCO}_{2}$ (and therefore the $\mathrm{H}^{+}$concentration) in the PVF is likely raised as 
observed in the cuttlefish eggs (i.e. $\mathrm{pCO}_{2}$ in PVF were 5-, 4- and 3-fold higher than in seawater, i.e. at 380, 850 and $1500 \mu$ atm, respectively, unpubl. data). As observed in the squid egg strands and shells, this increased $\mathrm{H}^{+}$concentration in the PVF might lower accumulation / adsorption of both elements in embryo. A not-restrictive but alternative explanation is that, in such conditions of hypoxia and hypercapnia within the egg, squid late embryos exhibit a metabolic depression (Guppy and Withers, 1999) - 2-fold lower oxygen consumption compared to the new hatchlings (Melzner et al., sbm) - that could be enhanced with increasing seawater $p \mathrm{CO}_{2}$ (Rosa and Seibel, 2008). This may therefore contribute to limit the accumulation of metals such as $\mathrm{Cd}$ and $\mathrm{Mn}$ in their tissues.

Secondly, regarding ${ }^{110 \mathrm{~m}} \mathrm{Ag},{ }^{57} \mathrm{Co},{ }^{203} \mathrm{Hg}$ and ${ }^{65} \mathrm{Zn}$, it is noteworthy that the more the metal is retained by the eggshell, the lower is the penetration in the embryo. More precisely, the behaviours of metals that are mainly retained by the external part of the eggshell (i.e. ${ }^{203} \mathrm{Hg}$ and ${ }^{65} \mathrm{Zn}$; Table 2), are particularly affected by $p \mathrm{CO}_{2}$. The Co, mainly associated with the inner layers of the eggshell (Table 2), showed an opposite behaviour with a limited penetration in the embryo (lowest $\mathrm{CF}$ values; Table 2) unaffected by the seawater $p \mathrm{CO}_{2}$. This result support the view that $p \mathrm{CO}_{2}$-induced modifications of metal binding and shielding properties of the external eggshell layers have a direct impact on the $\mathrm{Ag}, \mathrm{Hg}$ and $\mathrm{Zn}$ accumulation in the embryo that are mainly retained by these nidamental envelopes.

Following hatching, exposure of eggshell-free paralarvae to waterborne ${ }^{110 \mathrm{~m}} \mathrm{Ag},{ }^{203} \mathrm{Hg}$ and ${ }^{65} \mathrm{Zn}$ under hypercapnic conditions (Fig.3) reveals that $p \mathrm{CO}_{2}$ affects directly and significantly the $\mathrm{CF}$ values in squid early-life stages. Comparison of metal uptake in embryo and juvenile raises some hypotheses about the impact of the $p \mathrm{CO}_{2}$ on the mechanisms of $\mathrm{Hg}$, $\mathrm{Zn}$ and $\mathrm{Ag}$ accumulation in these organisms.

More precisely, $\mathrm{Hg}$ uptake in paralarvae was enhanced at $850 \mu \mathrm{atm}$ compared to the control and the highest $p \mathrm{CO}_{2}$ value, as previously observed on the whole egg strand. In cuttlefish juveniles, ${ }^{203} \mathrm{Hg}$ is mainly stored (up to $80 \%$ of the total $\mathrm{Hg}$ load) in muscles, skin and gills. This suggests that this metal is mainly bound to tissues directly exposed to contaminated seawater (Lacoue-Labarthe et al., 2009b) and that intermediate $p \mathrm{CO}_{2}$ could favour this $\mathrm{Hg}$ adsorption to the surface tissues of the paralarvae. However, further studies should be carried out, for instance using autoradiography, to confirm this hypothesised localisation of $\mathrm{Hg}$ ions in the cephalopod juveniles.

The bioaccumulation rate of ${ }^{65} \mathrm{Zn}$ in the paralarvae was not affected by the $p \mathrm{CO}_{2}$ treatments (Fig. 3), although it was still enhanced by increasing $p \mathrm{CO}_{2}$ in the embryo at the 
end of development (Fig. 2). This enhancement was also observed in the statoliths. This suggests that the incorporation of $\mathrm{Zn}$ in the statolith is proportional to the quantity of $\mathrm{Zn}$ bioaccumulated in the embryo. Alternatively, the increasing $\mathrm{Zn}$ incorporation in statoliths could be linked with increased growth of this calcified structure under low $\mathrm{pH}$ conditions as observed in fish otoliths (Checkley et al., 2009) and Sepioid cuttlebone (Gutowska et al., 2010a). This observation suggests that ocean acidification affects the incorporation rate of a metal that has been used as an environmental tracer in cephalopods (Ikeda et al. 1996, 2002; Lipinski et al. 1997; Zumholz et al. 2007) and hopefully will stimulate future research to investigate the possibility it could impact the incorporation of other trace elements used to track movements of marine organisms (Arkhipkin et al. 2004; Campana et al. 2000). Furthermore, $\mathrm{Zn}$ is a co-factor of carbonic anhydrase enzyme that is strongly involved in acidbase regulation (Addink, 1971) and therefore in compensation to hypercapnia-induced acidosis (Pörtner et al., 1989; Gutowska et al., 2010b). In this context, the high hypercapnia experienced by the late embryo in the PVF might enhance carbonic anhydrase synthesis and $\mathrm{Zn}$ requirements in the tissues. Further evaluation is now required to evaluate this hypothesis that increased $\mathrm{Zn}$ accumulation in organisms is related to $p \mathrm{CO}_{2}$-compensation in their physiological processes.

Acid-base regulation is coupled to ionic regulation as the transfers of $\mathrm{H}^{+}$and $\mathrm{HCO}_{3}{ }^{-}$ across biological membranes require an exchange with $\mathrm{Na}^{+}$and $\mathrm{Cl}^{-}$(e.g. Gilmour and Perry, 2009). In these processes, the $\mathrm{Na}^{+} / \mathrm{K}^{+}$-ATPase is thought to be the main mechanism of ion exchange by creating ion- and electrochemical gradients used by secondary active transporters (Evans et al. 2005; Gilmour and Perry, 2009). In marine organisms, the active uptake of sodium is the mechanism by which Ag penetrates across the gills (Webb and Wood, 2000; Grosell and Wood, 2001) and the inhibition of $\mathrm{Na}^{+} / \mathrm{K}^{+}$-ATPase is key to $\mathrm{Ag}$ toxicity (Bianchini et al., 2005). In a recent study, Hu et al. (2010) showed that the squid embryo and paralarvae display relatively low gill ion-regulatory capacities linked with less developed gill epithelia compared to the cuttlefish. However, both the normal development of squid and cuttlefish embryos under extreme abiotic conditions in the PVF (Melzner et al., sbm) and the higher Ag CF values reached in squid hatchlings $\left({ }^{110 \mathrm{~m}} \mathrm{Ag} \mathrm{CF}=2025 \pm 176\right.$ and $5537 \pm 2840$ in late stages embryos of cuttlefish and squid, respectively; Lacoue-Labarthe, sbm) suggest that another organ, e.g. skin or the yolk-sac membrane, might perform the ion-regulatory functions in squid embryo ( $\mathrm{Hu}$ et al., 2010). Thus, the increased $\mathrm{Ag}$ uptake with increasing $p \mathrm{CO}_{2}$ found in the present study both in the embryo and the paralarvae seems to result from 
enhanced compensation processes involving ionic regulation mechanisms, in response to hypercapnia.

In summary, this study confirms the appreciable and contrasting effects of $p \mathrm{CO}_{2}$ on the bioaccumulation of several metals at different early-life stages of the squid Loligo vulgaris. By comparing the uptake of multiple radiotracers between enclosed embryos and eggshell-free paralarvae, we hypothesize the following; i) the ocean acidification leads to combined effects of $\mathrm{pH} /$ protons on the binding efficiencies of biological surfaces and consequently on the protective properties of the eggshell (and especially the external envelopes), and ii) the hypercapnia affects the accumulation of metals in the biological tissues through disturbances to physiological processes of the organism. In the context of the ocean acidification, these results improve our knowledge of the ecotoxicological consequences of reduced or increased accumulation of essential and non-essential metals on the survival and recruitment success of early-life stages.

\section{Acknowledgments}

Thanks are due to S. Martin for her assistance during the experiments. The International Atomic Energy Agency is grateful to the Government of the Principality of Monaco for the support provided to its Environment Laboratories. This work was supported by the IAEA and LIENSs. This work is a contribution to the "European Project on Ocean Acidification" (EPOCA) which received funding from the European Community's Seventh Framework Programme (FP7/2007-2013) under grant agreement no. 211384. Mr André and Eric Rinaldi of Monaco are thanked for the collection of specimens. Anonymous reviewers are thankfully acknowledged for deeply improving the manuscript.

\section{References}

Addink, A.D.F., 1971. Carbonic anhydrase of Sepia officinalis L. Comp. Biochem. Physiol. 38B, 707721.

Arkhipkin, A.I., Laptikhovsky, V.V., 2010. Convergence in life-history traits in migratory deep-water squid and fish. ICES J. Mar. Sci. 67, 1444-1451.

Arkhipkin, A.I., Campana, S.E., Fitzgerals, J., Thorrold, S.R. 2004. Spatial and temporal variation in the elemental signatures of statoliths from the Patagonian longfin squid (Loligo gahi). Can. J. Fish. Aquat. Sci. 61, 1212-1224. 
Barbieri, E., Barry, K., Child, A., Wainwright, N., 1997. Antimicrobial activity in the microbial community of the accessory nidamental gland and egg cases of Loligo pealei (Cephalopoda: Loliginidae). Biol. Bull. 193, 275-276.

Bianchini, A., Playle, R.C., Wood, C.M., Walsh, P.J., 2005. Mechanism of acute silver toxicity in marine invertebrates. Aquat. Toxicol. 72, 67-82.

Bibby, R., Widdicombe, S., Parry, H.E., Spicer, J.I., Pipe, R.K., 2008. Effects of ocean acidification on the immune response of the blue mussel Mytilus edulis. Aquat. Biol. 2, 67-74.

Boletzky, S.V., 1986. Encapsulation of cephalopod embryos: a search for functional correlations. Am. Malacol. Bull. 4, 217-227.

Bridges, C.R., 1994. Bohr and Root effects in cephalopods. In: Pörtner, H.-O., O'Dor, R.K., Macmillan, D.L. (Eds.), Physiology of cephalopod molluscs: lifestyle and performance adaptations. Gordon and Breach Science Publishers, Basel, Switzerland, pp. 121-130.

Bruland, K. D., 1983. Trace elements in seawater, edited by: Riley, J. P. and Chester, R., Chemical oceanography, 8. Academic Press, London, 157-201.

Bustamante, P., Teyssié, J.-L., Danis, B., Fowler, S.W., Miramand, P., Cotret, O., Warnau, M., 2004. Uptake, transfer and distribution of silver and cobalt in tissues of the common cuttlefish Sepia officinalis at different stages of its life cycle. Mar. Ecol. Prog. Ser. 269, 185-195.

Bustamante, P., Teyssié, J.-L., Fowler, S.W., Cotret, O., Danis, B., Miramand, P., Warnau, M., 2002. Biokinetics of zinc and cadmium accumulation and depuration at different stages in the life cycle of the cuttlefish Sepia officinalis. Mar. Ecol. Prog. Ser. 231, 167-177.

Bustamante, P., Teyssié, J.-L., Fowler, S.W., Warnau, M., 2006. Contrasting bioaccumulation and transport behaviour of two artificial radionuclides $\left({ }^{241} \mathrm{Am}\right.$ and $\left.{ }^{134} \mathrm{Cs}\right)$ in cuttlefish eggshell. Vie Milieu 56, 153-156.

Byrne, R.H., Kump, L.R., Cantrell, K.J., 1988. The influence of temperature and pH on trace metal speciation in seawater. Mar. Chem. 25, 163-181.

Byrne, R.H., 2002. Inorganic speciation of dissolved elements in seawater: the influence of $\mathrm{pH}$ on concentration ratios. Geochem. Trans. 2, 11-16.

Caldeira, K., Wickett, M., 2005. Ocean model predictions of chemistry changes from carbon dioxide emissions to the atmosphere and ocean. J. Geophys. Res. 110C, 1-12.

Campana, S.E., Chouinard, G.A., Hanson, J.M., Fréchet, A., Brattey, J., 2000. Otolith elemental fingerprints as biological tracers of fish stocks. Fish. Res. 46, 343-357.

Carvalho, C.S., Fernandes, M.N., 2006. Effect of temperature on copper toxicity and hematological responses in the neotropical fish Prochilodus scrofa at low and high $\mathrm{pH}$. Aquaculture 251, 109-117.

Checkley Jr., D.M., Dickson, A.G., Takahashi, M., Radich, J.A., Eisenkolb, N., Asch, R. 2009. Elevated CO2 enhances otolith growth in young fish. Science 324, 1683.

Cronin, E.R., Seymour, R.S., 2000. Respiration of the eggs of the giant cuttlefish Sepia apama. Mar. Biol. 136, 863-870.

Deigweiher, K., Koschnick, N., Pörtner, H.-O., Lucassen, M., 2008. Acclimation of ion regulatory capacities in gills of marine fish under environmental hypercapnia. Am. J. Physiol. Regul. Integr. Comp. Physiol. 295, R1660-R1670.

Dickson, A.G., Sabine, C.L., Christian, J.R., 2007. Determination of the $\mathrm{pH}$ of sea water using a glass / reference electrode cell. In: Dickson, A.G., Sabine, C.L., Christian, J.R. (Eds.), Guide to best practices for ocean $\mathrm{CO}_{2}$ measurements. PICES Special Publication 3, pp. 1-7.

Dupont, S., Ortega-Martinez, O., Thorndyke, M., 2010. Impact of near-future ocean acidification on echinoderms. Ecotoxicology 19, 449-462.

Dupont, S., Thorndyke, M.C., 2009. Impact of $\mathrm{CO}_{2}$-driven ocean acidification on invertebrates early life-history: What we know, what we need to know and what we can do. Biogeosciences Discuss. 6, 3109-3131.

Doney, S.C., Fabry, V.J., Feely, R.A., Kleypas, J., 2009. Ocean acidification: the other $\mathrm{CO}_{2}$ problem. Annu. Rev. Mar. Sci. 1, 169-192.

Evans, D.H., Piermarini, P.M., Choe, K.P., 2005. The multifunctional fish gill: dominant site of gas exchange, osmoregulation, acid-base regulation and excretion of nitrogenous waste. Physiol. Rev. 85, 97-177. 
Feely, R.A., Sabine, C.L., Lee, K., Berelson, W., Kleypas, J., Fabry, V.J., Millero, F.J., 2004. Impact of anthropogenic $\mathrm{CO}_{2}$ on the $\mathrm{CaCO}_{3}$ system in the oceans. Science 305, 362-366.

Findlay, H.S., Kendall, M.A., Spicer, J.I., Widdicombe, S., 2010. Post-larval development of two intertidal barnacles at elevated $\mathrm{CO}_{2}$ and temperature. Mar. Biol. 157, 725-735.

Gattuso, J.-P., Frankignoulle, M., Bourge, I., Romaine, S., Buddemeier, R. W., 1998. Effect of calcium carbonate saturation of seawater on coral calcification. Global Planet. Change 18, 3746.

Gattuso J.-P., Allemand, D., Frankignoulle, M., 1999. Photosynthesis and calcification at cellular, organismal and community levels in coral reefs: a review on interactions and control by carbonate chemistry. Amer. Zool. 39, 160-183.

Gilmour, K.M., Perry, S.F., 2009. Review: Carbonic anhydrase and acid-base regulation in fish. J. Exp. Biol. 212, 1647-1661.

Grosell, M., Wood, C.M., 2001. Branchial versus intestinal silver toxicity and uptake in the marine teleost Parophrys vetulus. J. Comp. Physiol. 171B, 585-594.

Guppy, M., Withers, P., 1999. Metabolic depression in animals: physiological perspectives and biochemical generalizations. Biol. Rev. Camb. Philos. 74, 1-40.

Gutowska, M.A., Melzner, F., 2009. Abiotic conditions in cephalopod (Sepia officinalis) eggs: embryonic development at low $\mathrm{pH}$ and high $p \mathrm{CO}_{2}$. Mar. Biol. 156, 515-519.

Gutowska, M.A., Melzner, F., Langenbuch, M., Bock, C., Claireaux, G., Pörtner, H.-O., 2010b. Acidbase regulatory ability of the cephalopod (Sepia officinalis) in response to environmental hypercapnia. J. Comp. Physiol. 180, 323-335.

Gutowska, M.A., Melzner, F., Pörtner, H.-O., Meier, S., 2010a. Cuttlebone calcification increases during exposure to elevated seawater $p \mathrm{CO}_{2}$ in the cephalopod Sepia officinalis. Mar. Biol. 157, 1653-1663.

Harley, C.D.G., Hughes, A.R., Hultgren, K.M., Miner, B.G., Sorte, C.J.B., Thornber, C.S., Rodriguez, L.F., Tomanek, L., Williams, S.L., 2006. The impacts of climate change in coastal marine systems. Ecol. Lett. 9, 228-241.

Hu, M., Sucré, E., Charmantier-Daures, M., Charmantier, G., Lucassen, M., Himmerkus, N., Melzner, F., 2010. Localization of ion-regulatory epithelia in embryos and hatchlings of two cephalopods. Cell Tissue Res. 339, 571-583.

Ikeda, Y., Arai, N., Sakamoto, W., Kidokoro, H., Yoshida, K. 1996. Relationship between statoliths and environmental variables in Cephalopod. Int. J. PIXE 6, 339-345.

Ikeda, Y., Yatsu, A., Arai, N., Sakamoto, W. 2002. Concentration of statolith trace elements in the jumbo flying squid during El Niño and non-El Niño years in the eastern Pacific. J. Mar. Biol. Ass. U.K. 82, 863-866.

IPCC (2007). Climate Change 2007: Synthesis Report. Contribution of Working Groups I, II and III to the Fourth Assessment Report of the Intergovernmental Panel on Climate Change, $104 \mathrm{p}$. IPCC, Geneva.

Kurihara, H., 2008. Effects of $\mathrm{CO}_{2}$-driven ocean acidification on the early developmental stages of invertebrates. Mar. Ecol. Prog. Ser. 373, 275-284.

Lacoue-Labarthe, T., Martin, S., Oberhänsli, F., Teyssie, J.-L., Markich, S.J., Jeffree, R., Bustamante, P., 2009a. Effects of increased $p \mathrm{CO}_{2}$ and temperature on trace element (Ag, $\mathrm{Cd}$ and $\mathrm{Zn}$ ) bioaccumulation in the eggs of the common cuttlefish, Sepia officinalis. Biogeosciences 6, 2561-2573.

Lacoue-Labarthe, T., Oberhänsli, F.R., Teyssié, J.-L., Warnau, M., Koueta, N., Bustamante, P., 2008. Differential bioaccumulation behaviour of $\mathrm{Ag}$ and $\mathrm{Cd}$ during the early development of the cuttlefish Sepia officinalis. Aquat. Toxicol. 86, 437-446.

Lacoue-Labarthe, T., Warnau, M., Oberhänsli, F., Teyssié, J.-L., Bustamante, P., 2009b. Bioaccumulation of inorganic $\mathrm{Hg}$ by the juvenile cuttlefish Sepia officinalis exposed to ${ }^{203} \mathrm{Hg}$ radiolabelled seawater and food. Aquat. Biol. 6, 91-98.

Lacoue-Labarthe, T., Warnau, M., Oberhänsli, F., Teyssié, J.-L., Bustamante, P., 2010. Contrasting accumulation biokinetics and distribution of ${ }^{241} \mathrm{Am}, \mathrm{Co}, \mathrm{Cs}, \mathrm{Mn}$ and $\mathrm{Zn}$ during the whole development time of the eggs of the common cuttlefish, Sepia officinalis. J. Exp. Mar. Biol. Ecol. 382, 131-138. 
Lannig, G., Eilers, S., Pörtner, H.-O., Sokolova, I.M., Bock, C., 2010. Impact of ocean acidification on energy metabolism of oyster, Crassostrea gigas - changes in metabolic pathways and thermal response. Mar. Drugs 8, 2318-2339.

Lavigne, H. and Gattuso, J.-P. (2010). seacarb: seawater carbonate chemistry with R. R package version 2.3.3. http://cran-project.org/package $=$ seacarb

Lipinski, M.R., Przybylowicz, W.J., Durholtz, M.D., Mesjasz-Przybylowicz, J. 1997. Quantitative micro-PIXE mapping of squid statoliths. Nucl. Instr. and Meth. in Phys. Res. B 130, 374-380.

Melzner, F., Gutowska, M.A., Langenbuch, M., Dupont, S., Lucassen, M., Thorndyke, M.C., Bleich, M., Pörtner, H.-O., 2009. Physiological basis for high $\mathrm{CO}_{2}$ tolerance in marine ectothermic animals: pre-adaptation through lifestyle and ontogeny? Biogeosciences 6, 2313-2331.

Metian, M., Bustamante, P., Hédouin, L., Oberhänsli, F., Warnau, M., 2009. Delineation of heavy metal uptake pathways (seawater and food) in the variegated scallop Chlamys varia, using radiotracer techniques. Mar. Ecol. Prog. Ser. 375, 161-171.

Millero, F.J., Woosley, R., Ditrolo, B., Waters, J., 2009. Effect of ocean acidification on the speciation of metals in seawater. Oceanography $22,72-85$.

Munday, P.L., Dixson, D.L., Donelson, J.M., Jones, G.P., Pratchett, M.S., Devitsina, G.V., Doving, K.B., 2009. Ocean acidification impairs olfactory discrimination and homing ability of a marine fish. Proc. Natl. Acad. Sci. U. S. A. 106, 1848-1852.

Nieboer, E., Richardson, D.H.S., 1980. The replacement of the nondescript term 'heavy metal' by a biologically and chemically significant classification of metal ions. Environ. Pollut. 1, 3-26.

Nixon, M., Mangold, K., 1998. The early stage of Sepia officinalis, and the contrast with that of Octopus vulgaris (Cephalopoda). J. Zool. 245, 407-421.

O'Dor, R.K., Webber, D.M., 1986. The constraints on cephalopods: why squid aren't fish. Can. J. Zool. 64, 1591-1605.

Orr, J.C., Fabry, V.J., Aumont, O., Bopp, L., Doney, S.C., Feely, R.A., Gnanadesikan, A., Gruber, N., Ishida, A., Joos, F., Key, R.M., Lindsay, K., Maier-Reimer, E., Matear, R., Monfray, P., Mouchet, A., Najjar, R.G., Plattner, G.K., Rodgers, K.B., Sabine, C.L., Sarmiento, J.L., Schlitzer, R., Slater, R.D., Totterdell, I.J., Weirig, M.F., Yamanaka, Y., Yool, A., 2005. Anthropogenic ocean acidification over the twenty-first century and its impact on calcifying organisms. Nature 437, 681-686.

Orr, J.C., in press. Recent and future changes in ocean carbonate chemistry. In: J.-P. Gattuso and L. Hansson (eds.), Ocean acidification, pp. x. Oxford University Press, Oxford.

Packard, A., 1972. Cephalopods and fish: the limits of convergence. Biol. Rev. 47, 241-307.

Pascal, P.-Y., Fleeger, J.W., Galvez, F., Carman, K.R., 2010. The toxicological interaction between ocean acidity and metals in coastal meiobenthic copepods. Mar. Pollut. Bull. 60, 2201-2208.

Pörtner, H.-O., 1989. The importance of metabolism in acid-base regulation and acid-base methodology. Can. J. Zool. 67, 3005-3017.

Pörtner, H.-O., 2008. Ecosystem effects of ocean acidification in times of ocean warming: A physiologist's view. Mar. Ecol. Prog. Ser. 373, 203-217.

Pörtner, H.-O., Farrell, A.P., 2008. Physiology and climate change. Science 322, 690-692.

Pörtner, H.-O., Zielinski, S., 1998. Environmental constraints and the physiology of performance in squids. S. Afr. J. Mar. Sci. 20, 207-221.

R Development Core Team, 2008. R: a language and environment for statistical computing, Vienna, Austria: R Foundation for Statistical Computing, accessed: http://www.R-project.org.

Rainbow, P.S., 1997a. Ecophysiology of trace metal uptake in crustaceans. Estuar. Coast. Shelf Sci. 44, 169-175.

Rainbow, P.S., 1997b. Trace metal accumulation in marine invertebrates: Marine biology or marine chemistry? J. Mar. Biol. Assoc. U. K. 77, 195-210.

Rosa, R., Seibel, B.A., 2008. Synergistic effects of climate-related variables suggest future physiological impairment in a top oceanic predator. Proc. Natl. Acad. Sci. U. S. A. 105, 20776-20780.

Sabine, C.L., Feely, R.A., Gruber, N., Key, R.M., Lee, K., Bullister, J.L., Wanninkhof, R., Wong, C.S., Wallace, D.W.R., Tilbrook, B., Millero, F.J., Peng, T.H., Kozyr, A., Ono, T., Rios, A.F., 2004. The oceanic sink for anthropogenic $\mathrm{CO}_{2}$. Science $305,367-371$. 
Shi, D., Xu, Y., Hopkinson, B.M., Morel, F.M.M., 2010. Effect of ocean acidification on iron availability to marine phytoplankton. Science 327, 676-679.

Talmage, S.C., Gobler, C.J., 2010. Effects of past, present, and future ocean carbon dioxide concentrations on the growth and survival of larval shellfish. Proc. Natl. Acad. Sci. U. S. A. $107,17246-17251$.

Webb, N.A., Wood, C.M., 2000. Bioaccumulation and distribution of silver in four marine teleosts and two marine elasmobranchs: influence of exposure duration, concentration, and salinity. Aquat. Toxicol. 49, 111-129.

Whicker, F. W. and Schultz, V., 1982. Radioecology : nuclear energy and the environment, edited by: Press, C., CRC Press, Boca Raton, FL.

Wood, C.M., 1992. Flux measurements as indices of $\mathrm{H}+$ and metal effects on freshwater fish. Aquat. Toxicol. 22, 239-263.

Worms, J., 1983. Loligo vulgaris. In: Boyle, P.R. (Ed.), Cephalopod life cycles, Vol.1. Academic Press, London, pp. 143-157.

Zumholz, K., Klügel, A., Hansteen, T., Piatkowski, U. 2007. Statolith microchemistry traces the environmental history of the boreatlantic armhook squid Gonatus fabricii. Mar. Ecol. Prog. Ser. 333, 195-204. 
1 Table 1. Loligo vulgaris. Parameters of ${ }^{110 \mathrm{~m}} \mathrm{Ag},{ }^{109} \mathrm{Cd},{ }^{57} \mathrm{Co},{ }^{203} \mathrm{Hg},{ }^{54} \mathrm{Mn}$, and ${ }^{65} \mathrm{Zn}$ uptake kinetics in the squid egg strands ( $\mathrm{n}=4$ ) and paralarvae

$2(\mathrm{n}=5$ pools of 5-10 individuals) exposed for the whole development time and for $52 \mathrm{~h}$, respectively, to radiotracers dissolved in seawater in three

$3 \mathrm{pH}$ levels treatments (see Figure 1 and 3):

\begin{tabular}{|c|c|c|c|c|c|c|c|c|c|c|c|}
\hline \multirow[b]{2}{*}{ Metal } & \multirow[b]{2}{*}{$\mathrm{pH}$} & \multicolumn{5}{|c|}{ Uptake kinetics in egg strands } & \multicolumn{5}{|c|}{ Uptake kinetics in paralarvae } \\
\hline & & Model & $\mathrm{k}_{\mathrm{u}}\left(\mathrm{d}^{-1}\right)$ & $\mathrm{CF}_{\mathrm{ss}} \pm \mathrm{SE}$ & $\mathrm{k}_{\mathrm{e}}\left(\mathrm{d}^{-1}\right)$ & $R^{2}$ & Model & $\mathrm{k}_{\mathrm{u}}\left(\mathrm{d}^{-1}\right)$ & $\mathrm{CF}_{\mathrm{ss}} \pm \mathrm{SE}$ & $\mathrm{k}_{\mathrm{e}}\left(\mathrm{d}^{-1}\right)$ & $R^{2}$ \\
\hline \multirow[t]{3}{*}{$\mathrm{Ag}$} & 7.60 & $\mathrm{C}$ & $0.050 *(a)$ & $161 \pm 33(\mathrm{a})$ & $0.260 * *$ & 0.943 & $\mathrm{E}$ & - & $2382 \pm 68(a)$ & $0.186^{* * *}$ & 0.960 \\
\hline & 7.85 & $\mathrm{C}$ & $0.078 * * *(b)$ & $152 \pm 17(\mathrm{a})$ & $0.295 * * *$ & 0.985 & $\mathrm{E}$ & - & $1948 \pm 116(b)$ & $0.133 * * *$ & 0.863 \\
\hline & 8.10 & $\mathrm{C}$ & $0.045 * *(a)$ & $159 \pm 24(a)$ & $0.249 * * *$ & 0.977 & $\mathrm{E}$ & - & $1357 \pm 67(\mathrm{c})$ & $0.379 *$ & 0.893 \\
\hline \multirow[t]{3}{*}{$\mathrm{Cd}$} & 7.60 & $\mathrm{E}$ & - & $37 \pm 4(\mathrm{a})$ & $0.112 * * *$ & 0.722 & $\mathrm{E}$ & - & - & - & \\
\hline & 7.85 & $\mathrm{E}$ & - & $29 \pm 2(b)$ & $0.310 * * *$ & 0.595 & $\mathrm{E}$ & - & - & - & \\
\hline & 8.10 & $\mathrm{E}$ & - & $77 \pm 5(\mathrm{c})$ & $0.164 * * *$ & 0.842 & $\mathrm{~L}$ & - & - & - & - \\
\hline \multirow[t]{3}{*}{$\mathrm{Co}$} & 7.60 & $\mathrm{~L}$ & $4.488^{* * *}$ (a) & - & - & 0.970 & $\mathrm{E}$ & - & $7 \pm 1$ (a) & $0.051 * *$ & 0.879 \\
\hline & 7.85 & $\mathrm{~L}$ & $4.942 * * *$ (a) & - & - & 0.979 & $\mathrm{E}$ & - & $15 \pm 5(a b)$ & $0.027^{\mathrm{ns}}$ & 0.807 \\
\hline & 8.10 & $\mathrm{~L}$ & $4.978 * * *$ (a) & - & - & 0.941 & $\mathrm{E}$ & - & $18 \pm 5(b)$ & $0.018^{*}$ & 0.943 \\
\hline \multirow[t]{3}{*}{$\mathrm{Hg}$} & 7.60 & $\mathrm{E}$ & - & $334 \pm 9$ (a) & $0.248 * * *$ & 0.902 & $\mathrm{~L}$ & $1.573 * * *(\mathrm{a})$ & - & - & 0.912 \\
\hline & 7.85 & $\mathrm{E}$ & - & $371 \pm 9$ (b) & $0.295 * * *$ & 0.892 & $\mathrm{~L}$ & $2.222 * * *(b)$ & - & - & 0.964 \\
\hline & 8.10 & $\mathrm{E}$ & - & $292 \pm 8(\mathrm{c})$ & $0.247 * * *$ & 0.922 & $\mathrm{~L}$ & $1.448 * * *(a)$ & - & - & 0.938 \\
\hline \multirow[t]{3}{*}{$\mathrm{Mn}$} & 7.60 & $\mathrm{E}$ & - & $50 \pm 3(a)$ & $0.180 * * *$ & 0.819 & $\mathrm{~L}$ & $0.455^{* * *}$ (a) & - & - & 0.975 \\
\hline & 7.85 & $\mathrm{E}$ & - & $78 \pm 6(b)$ & $0.093 * * *$ & 0.886 & $\mathrm{~L}$ & $0.536 * * *$ (a) & - & - & 0.961 \\
\hline & 8.10 & $\mathrm{E}$ & - & $113 \pm 5(\mathrm{c})$ & $0.105 * * *$ & 0.966 & $\mathrm{~L}$ & $0.518 * * *$ (a) & - & - & 0.974 \\
\hline \multirow[t]{3}{*}{$\mathrm{Zn}$} & 7.60 & $\mathrm{E}$ & - & $201 \pm 18(a)$ & $0.076^{* * *}$ & 0.914 & $\mathrm{~L}$ & $0.748 * * *(a)$ & - & - & 0.965 \\
\hline & 7.85 & $\mathrm{E}$ & - & $208 \pm 10(a)$ & $0.083 * * *$ & 0.962 & $\mathrm{~L}$ & $0.979 * * *$ (a) & - & - & 0.940 \\
\hline & 8.10 & $\mathrm{E}$ & - & $299 \pm 16(b)$ & $0.074 * * *$ & 0.978 & $\mathrm{~L}$ & $0.848 * * *(a)$ & - & - & 0.896 \\
\hline
\end{tabular}

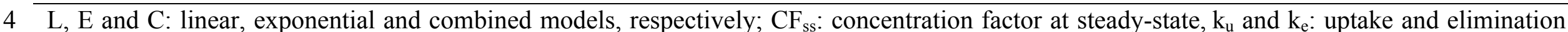

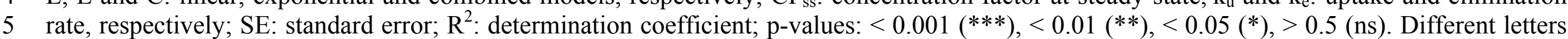
6 denote statistically significant differences $(\mathrm{F}$ test; $\mathrm{p}<0.05)$ between the sample $\mathrm{pH}$. 
7 Table 2. Loligo vulgaris. Radiotracers distribution ( $\%$; mean $\pm \mathrm{SD}, \mathrm{n}=3)$ and $\mathrm{CF}$ in brackets (mean $\pm \mathrm{SD}$, $\mathrm{n}=3)$ in the different compartments

8 of the squid egg strand (the eggshell from which external and internal layers were separated, embryos, and the perivitelline fluid) at the end of

9 development (stage 29-30) after a whole development time exposure to radiotracers dissolved in seawater in three $\mathrm{pH}$ levels treatments.

\begin{tabular}{|c|c|c|c|c|c|c|c|c|c|}
\hline & \multicolumn{3}{|c|}{${ }^{110 m} \mathrm{Ag}$} & \multicolumn{3}{|c|}{${ }^{109} \mathrm{Cd}$} & \multicolumn{3}{|c|}{${ }^{57} \mathrm{Co}$} \\
\hline & 7.60 & 7.85 & 8.10 & 7.60 & 7.85 & 8.10 & 7.60 & 7.85 & 8.10 \\
\hline Eggshell & $\begin{array}{l}37.3 \pm 12.4 \\
(187 \pm 58)^{\mathrm{c}}\end{array}$ & $\begin{array}{c}52.4 \pm 6.5 \\
(425 \pm 102)^{\mathrm{b}}\end{array}$ & $\begin{array}{l}54.5 \pm 16.2 \\
(255 \pm 74)^{\mathrm{a}}\end{array}$ & $\begin{array}{l}92.9 \pm 3.2 \\
(63 \pm 20)^{\mathrm{a}}\end{array}$ & $\begin{array}{l}92.4 \pm 3.6 \\
(86 \pm 27)^{\mathrm{a}}\end{array}$ & $\begin{array}{c}92.7 \pm 4.4 \\
(165 \pm 58)^{\mathrm{b}}\end{array}$ & $\begin{array}{l}91.8 \pm 4.7 \\
(211 \pm 39) \mathrm{a}\end{array}$ & $\begin{array}{l}92.5 \pm 2.0 \\
(246 \pm 34) \mathrm{a}\end{array}$ & $\begin{array}{c}90.3 \pm 11.2 \\
(214 \pm 104) \mathrm{a}\end{array}$ \\
\hline External part & $18.9 \pm 10.4$ & $22.6 \pm 8.4$ & $35.4 \pm 12.8$ & $40.1 \pm 20.1$ & $68.8 \pm 7.5$ & $54.7 \pm 16.4$ & $22.7 \pm 10.5$ & $20.6 \pm 4.7$ & $23.5 \pm 12.1$ \\
\hline Internal part & $18.4 \pm 6.8$ & $29.9 \pm 8.0$ & $19.1 \pm 8.9$ & $52.8 \pm 18.5$ & $23.7 \pm 5.9$ & $38.0 \pm 15.6$ & $69.1 \pm 9.3$ & $71.9 \pm 5.2$ & $66.6 \pm 21.5$ \\
\hline Embryo & $\begin{array}{c}61.8 \pm 12.5 \\
(10200 \pm 1350)^{b}\end{array}$ & $\begin{array}{c}46.9 \pm 6.8 \\
(8587 \pm 43)^{\mathrm{a}}\end{array}$ & $\begin{array}{c}44.9 \pm 16.2 \\
(9341 \pm 457)^{\mathrm{a}}\end{array}$ & $\begin{array}{c}5.2 \pm 2.8 \\
(109 \pm 52)^{\mathrm{b}}\end{array}$ & $\begin{array}{c}6.8 \pm 3.8 \\
(142 \pm 83)^{b}\end{array}$ & $\begin{array}{c}6.8 \pm 4.3 \\
(505 \pm 299)^{\mathrm{a}}\end{array}$ & $\begin{array}{c}0.9 \pm 0.2 \\
(63 \pm 16)^{\mathrm{a}}\end{array}$ & $\begin{array}{c}1.0 \pm 0.4 \\
(67 \pm 37)^{\mathrm{a}}\end{array}$ & $\begin{array}{c}7.7 \pm 10.6 \\
(347 \pm 378)^{\mathrm{a}}\end{array}$ \\
\hline \multirow[t]{3}{*}{ Perivitelline fluid } & $\begin{array}{l}1.0 \pm 0.7 \\
(32 \pm 10)\end{array}$ & $\begin{array}{l}0.7 \pm 0.4 \\
(43 \pm 33)\end{array}$ & $\begin{array}{l}0.6 \pm 0.5 \\
(60 \pm 86)\end{array}$ & $\begin{array}{l}2.2 \pm 1.7 \\
(<15)\end{array}$ & $\begin{array}{l}<1 \\
(<5)\end{array}$ & $\begin{array}{l}<1 \\
(<5)\end{array}$ & $\begin{array}{c}8.3 \pm 4.3 \\
(139 \pm 29)\end{array}$ & $\begin{array}{c}6.4 \pm 2.0 \\
(126 \pm 13)\end{array}$ & $\begin{array}{l}2.3 \pm 1.7 \\
(88 \pm 48)\end{array}$ \\
\hline & \multicolumn{3}{|c|}{${ }^{203} \mathrm{Hg}$} & \multicolumn{3}{|c|}{${ }^{54} \mathrm{Mn}$} & \multicolumn{3}{|c|}{${ }^{65} \mathrm{Zn}$} \\
\hline & 7.60 & 7.85 & 8.10 & 7.60 & 7.85 & 8.10 & 7.60 & 7.85 & 8.10 \\
\hline Eggshell & $\begin{array}{c}97.3 \pm 1.2 \\
(959 \pm 129)^{\mathrm{ab}}\end{array}$ & $\begin{array}{c}98.3 \pm 0.3 \\
(1088 \pm 102)^{b}\end{array}$ & $\begin{array}{c}98.1 \pm 1.5 \\
(935 \pm 129)^{\mathrm{a}}\end{array}$ & $\begin{array}{c}96.8 \pm 0.9 \\
(102 \pm 15)^{b}\end{array}$ & $\begin{array}{c}98.2 \pm 0.6 \\
(177 \pm 49)^{\mathrm{a}}\end{array}$ & $\begin{array}{l}96.0 \pm 2.4 \\
(201 \pm 50)^{\mathrm{a}}\end{array}$ & $\begin{array}{c}70.7 \pm 8.4 \\
(199 \pm 36)^{\mathrm{c}}\end{array}$ & $\begin{array}{c}72.9 \pm 7.0 \\
(285 \pm 86)^{\mathrm{b}}\end{array}$ & $\begin{array}{c}90.3 \pm 5.2 \\
(422 \pm 108)^{\mathrm{a}}\end{array}$ \\
\hline External part & $84.4 \pm 6.6$ & $85.6 \pm 8.2$ & $92.3 \pm 3.4$ & $64.7 \pm 11.4$ & $69.8 \pm 10.0$ & $80.2 \pm 6.4$ & $35.4 \pm 14.0$ & $54.1 \pm 13.7$ & $66.0 \pm 12.8$ \\
\hline Internal part & $12.9 \pm 5.9$ & $12.7 \pm 8.3$ & $5.8 \pm 3.2$ & $32.0 \pm 10.6$ & $28.4 \pm 9.6$ & $15.2 \pm 5.7$ & $35.3 \pm 8.3$ & $18.8 \pm 7.9$ & $24.0 \pm 12.6$ \\
\hline Embryo & $\begin{array}{c}2.5 \pm 1.2 \\
(752 \pm 112)^{\mathrm{a}}\end{array}$ & $\begin{array}{c}1.5 \pm 0.2 \\
(394 \pm 93)^{\mathrm{b}}\end{array}$ & $\begin{array}{c}1.8 \pm 0.1 \\
(662 \pm 326)^{\mathrm{a}}\end{array}$ & $\begin{array}{c}3.1 \pm 1.0 \\
(103 \pm 20)^{\mathrm{b}}\end{array}$ & $\begin{array}{c}1.8 \pm 0.6 \\
(75 \pm 37)^{b}\end{array}$ & $\begin{array}{c}4.0 \pm 2.4 \\
(311 \pm 70)^{\mathrm{a}}\end{array}$ & $\begin{array}{c}29.1 \pm 8.4 \\
(2613 \pm 398)^{b}\end{array}$ & $\begin{array}{c}26.9 \pm 7.0 \\
(2337 \pm 733)^{\mathrm{ab}}\end{array}$ & $\begin{array}{c}9.9 \pm 5.2 \\
(1819 \pm 183)^{\mathrm{a}}\end{array}$ \\
\hline Perivitelline fluid & $\begin{array}{l}0.2 \pm 0.1 \\
(17 \pm 4)\end{array}$ & $\begin{array}{c}0.2 \pm 0.1 \\
(14 \pm 2)\end{array}$ & $\begin{array}{l}1.5 \pm 0.1 \\
(22 \pm 32)\end{array}$ & $\begin{array}{l}0.2 \pm 0.1 \\
\quad(<5)\end{array}$ & $\begin{array}{l}0.1 \pm 0.02 \\
\quad(<5)\end{array}$ & $\begin{array}{l}0.1 \pm 0.1 \\
\quad(<5)\end{array}$ & $\begin{array}{l}0.2 \pm 0.1 \\
\quad(<5)\end{array}$ & $\begin{array}{l}0.2 \pm 0.1 \\
\quad(<5)\end{array}$ & $\begin{array}{c}0.1 \pm 0.1 \\
(<5)\end{array}$ \\
\hline
\end{tabular}

10 Different letters denote statistically significant differences (Kruskall-Wallis test; $\mathrm{p}<0.05$ ) between the sample $\mathrm{pH}$. 


\section{Figures captions}

Fig. 1. Loligo vulgaris. ${ }^{110 \mathrm{~m}} \mathrm{Ag},{ }^{109} \mathrm{Cd},{ }^{57} \mathrm{Co},{ }^{203} \mathrm{Hg},{ }^{54} \mathrm{Mn}$ and ${ }^{65} \mathrm{Zn}$ uptake kinetics (CF; mean $\pm \mathrm{SD} ; \mathrm{n}=4)$ in the whole egg strands exposed to dissolved radiotracers at three different $\mathrm{pH}-$ pH 8.10 (1), pH 7.85 (p), pH 7.60 ( $\Delta$ ).

Fig. 2. Loligo vulgaris. Concentration factors of ${ }^{110 \mathrm{~m}} \mathrm{Ag},{ }^{109} \mathrm{Cd},{ }^{57} \mathrm{Co},{ }^{203} \mathrm{Hg},{ }^{54} \mathrm{Mn}$ and ${ }^{65} \mathrm{Zn}$ (CF; $n=9$ pools of 7-26 embryos from 3 egg strands), in the squid embryos exposed dissolved radiotracers at three different $\mathrm{pH}-\mathrm{pH} 8.10, \mathrm{pH} \mathrm{7.85,} \mathrm{pH} 7.60$ - for two development times, i.e. $16 \mathrm{~d}$ (stage 25-26; grey) and $26 \mathrm{~d}$ (stage 29-30; white). Results of the statistical analysis were reported on the Table 2.

Fig. 3. Loligo vulgaris. ${ }^{110 \mathrm{~m}} \mathrm{Ag},{ }^{57} \mathrm{Co},{ }^{203} \mathrm{Hg},{ }^{54} \mathrm{Mn}$ and ${ }^{65} \mathrm{Zn}$ uptake kinetics (CF; mean $\pm \mathrm{SD}$; $\mathrm{n}$ $=5$ pools of 5-10 individuals) in the squid paralarvae exposed to dissolved radiotracers at three different $\mathrm{pH}-\mathrm{pH} 8.10$ (1), $\mathrm{pH} 7.85$ (p), $\mathrm{pH} 7.60$ ( $\boldsymbol{\Delta}$ ). 

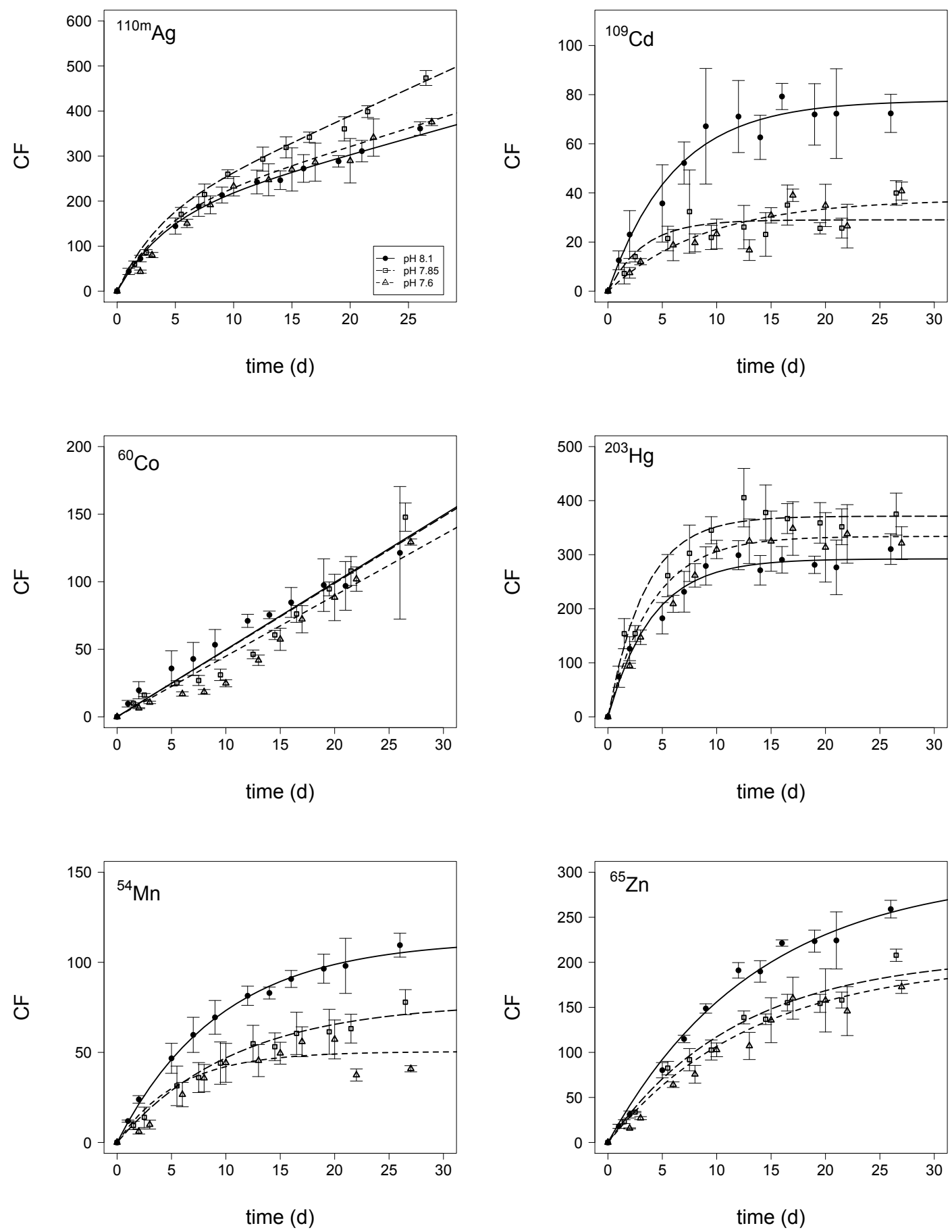

Fig. 1. 

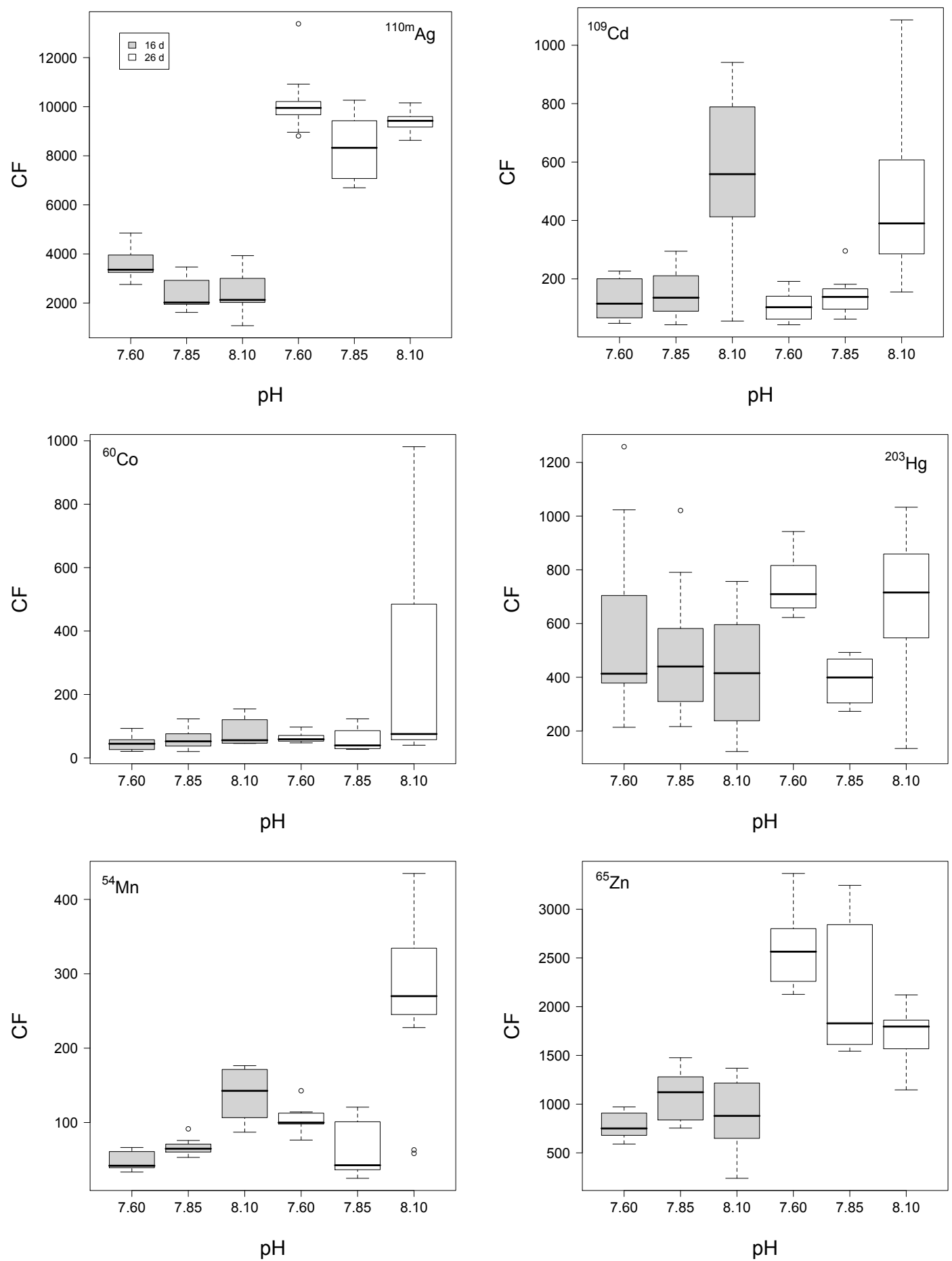

Fig. 2. 

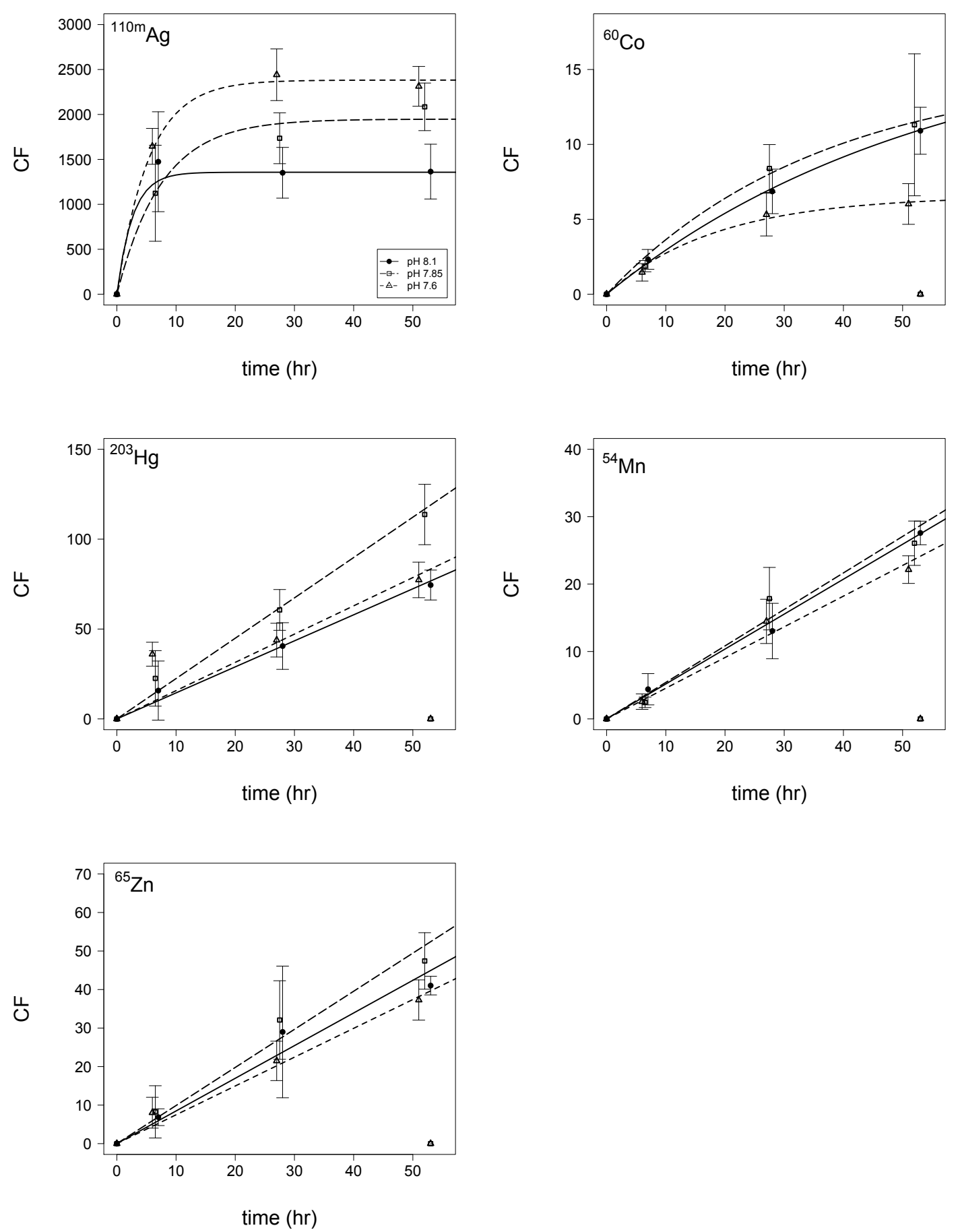

Fig. 3. 